Atrkivoc

Free to Authors and Readers
A Platinum Open Access Journal

for Organic Chemistry
Paper

Arkivoc 2021, part vi, 148-173

\title{
Polymerizable UV absorbers for the UV stabilization of polyesters. I. Design, synthesis and polymerization of a library of UV absorbing monomers
}

\author{
Peter A. G. Cormack, ${ }^{a^{*}}$ Omer C. Erdemlia and Stephen W. Sankey ${ }^{b}$ \\ ${ }^{a}$ WestCHEM, Department of Pure and Applied Chemistry, University of Strathclyde, Thomas Graham Building, \\ 295 Cathedral Street, Glasgow, G1 1XL, Scotland, UK \\ ${ }^{b}$ DuPont Teijin Films UK Limited, Wilton, Middlesbrough, TS10 4RF, England, UK \\ Email: Peter.Cormack@strath.ac.uk
}

Dedicated to Professor Phil Hodge for his outstanding lifetime achievements in organic and polymer chemistry

Received 06-16-2021

Accepted 08-08-2021

Published on line 09-16-2021

\section{Abstract}

UV stabilizers, such as Tinuvin 1577, are organic additives that are used in the polymer industry to suppress polymer photodegradation, however leaching of the stabilizers from polymers is a significant practical issue which limits the effectiveness of the stabilizers and restricts polymer lifetimes. Novel, polymerizable UV stabilizers were synthesised and copolymerized with bis(2-hydroxyethyl) isophthalate to yield poly(ethylene isophthalate) copolymers where the UV stabilizers are bound covalently into the polymer chains. This strategy prevents leaching of stabilizers from polymers over time, and is expected to lead to enhanced UV protection of polymers compared to the admixing of polymers with UV stabilizers of low molar mass.

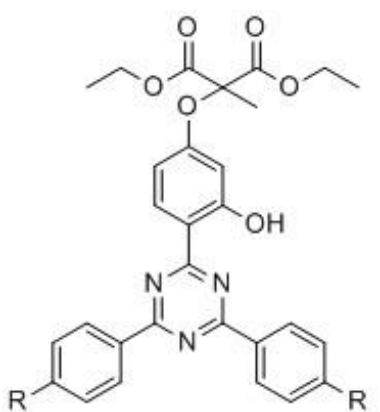

$$
\begin{aligned}
& 10 \mathrm{R}=\mathrm{H} \\
& 11 \mathrm{R}=\mathrm{Ar}
\end{aligned}
$$

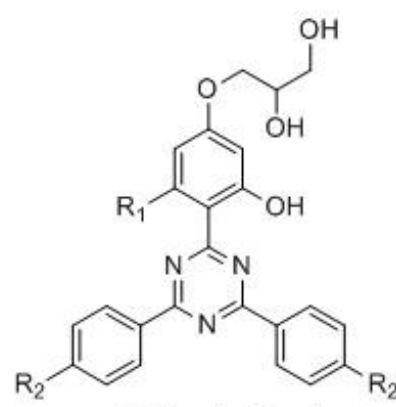

$12 \mathrm{R}_{1}=\mathrm{H}, \mathrm{R}_{2}=\mathrm{H}$ $13 \mathrm{R}_{1}=\mathrm{H}, \mathrm{R}_{2}=\mathrm{OCH}_{3}$ $14 R_{1}=H, R_{2}=F$ $15 \mathrm{R}_{1}=\mathrm{OH}, \mathrm{R}_{2}=\mathrm{H}$ $16 R_{1}=H, R_{2}=A r$

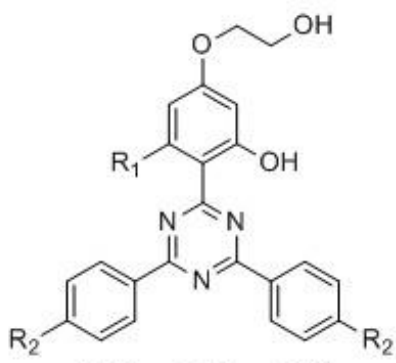

$17 \mathrm{R}_{1}=\mathrm{H}, \mathrm{R}_{2}=\mathrm{OCH}_{3}$ $18 R_{1}=H, R_{2}=F$ $19 R_{1}=\mathrm{OH}, \mathrm{R}_{2}=\mathrm{H}$

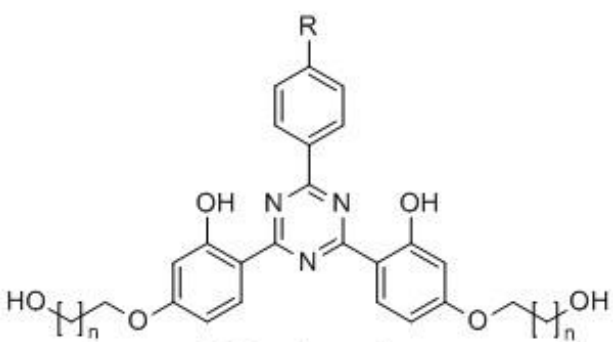

$24 \mathrm{R}=\mathrm{H}, \mathrm{n}=1$

$25 \mathrm{R}=\mathrm{H}, \mathrm{n}=8$

$26 \mathrm{R}=\mathrm{OCH}_{3}, \mathrm{n}=1$

Keywords: Ultraviolet, Degradation, Poly(ethylene terephthalate), Poly(ethylene isophthalate), UV absorber, Tinuvin 1577 


\section{Introduction}

Poly(ethylene terephthalate) (PET) absorbs strongly in the ultraviolet (UV) region of the EM spectrum (Figure 1), and this can lead to photodegradation of the polymer chains and loss of polymer properties. UV stabilizer additives are normally employed to suppress the UV-induced photodegradation of polyester films, especially for those applications where the levels of UV exposure to the polymer film are high, e.g., photovoltaic cells. ${ }^{1}$ One limitation concerning the use of UV stabilizers is the loss of additive from the polymers over time by leaching, since UV stabilizers are normally low molar mass organic compounds that can be washed out through weathering actions, and this reduces their effectiveness. One way in which this leaching problem can potentially be circumvented is to lock the UV stabilizers into the polymer chains through covalent bonds. ${ }^{2}$

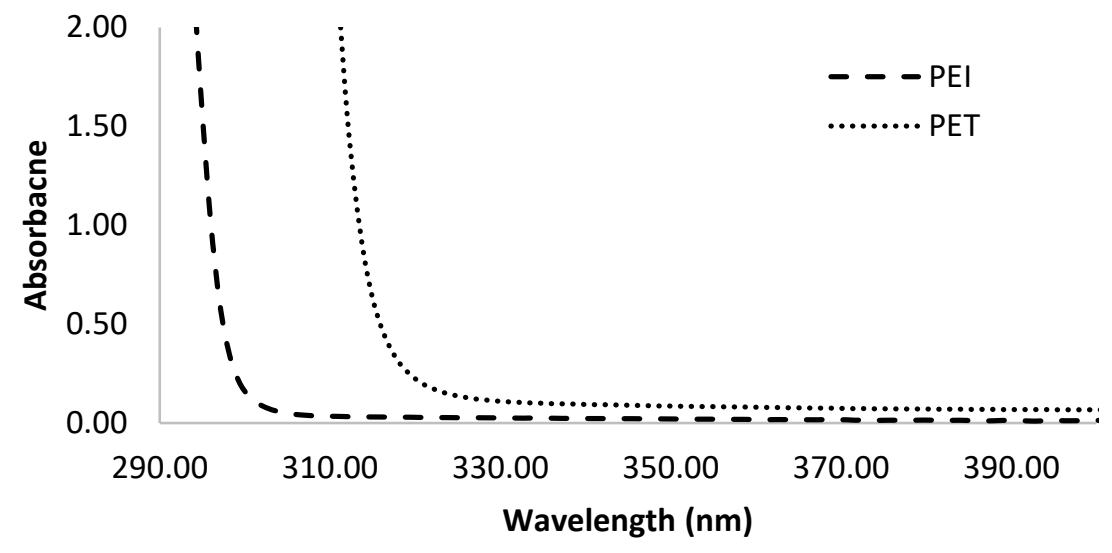

Figure 1. UV absorbance spectra of poly(ethylene isophthalate) (PEI) and poly(ethylene terephthalate) (PET).

\section{UV degradation of PET}

The photochemistry of polyester degradation is a complex area and has been studied extensively over the past fifty years. In the early 1970s, Day and Wiles ${ }^{3-6}$ proposed mechanisms (Figure 2 ) to explain the formation of the three main products $\left(-\mathrm{COOH}, \mathrm{CO}\right.$ and $\mathrm{CO}_{2}$ ) arising from the exposure of PET to oxidative and non-oxidative conditions. It was found that wavelengths below $310 \mathrm{~nm}$ were critical for main-chain scission and that wavelengths above $315 \mathrm{~nm}$ led to the production of $\mathrm{COOH}$ end groups. Day and Wiles postulated that carboxylic acid end groups were formed by a Norrish Type II photo-elimination reaction, involving an intramolecular rearrangement of the ester group into an olefin and carboxylic acid. $\mathrm{CO}$ build up was explained by a photolytic chain-scission, via a Norrish Type I reaction. The rate of $\mathrm{CO}_{2}$ formation increased greatly for irradiations conducted in the presence of air, so it was evident that oxygen played a role in the mechanism. Furthermore, the hydroxyl radicals formed could give rise to fluorescent mono-/di-hydroxyl terephthalate species.

Fechine $^{7-9}$ proposed an alternative mechanism, involving a Norrish Type I reaction which proceeded through a radical pathway in the presence of oxygen, and Rivaton et $a . .^{10}$ reported further oxidation of aldehyde to produce additional carboxylic acid end groups. 


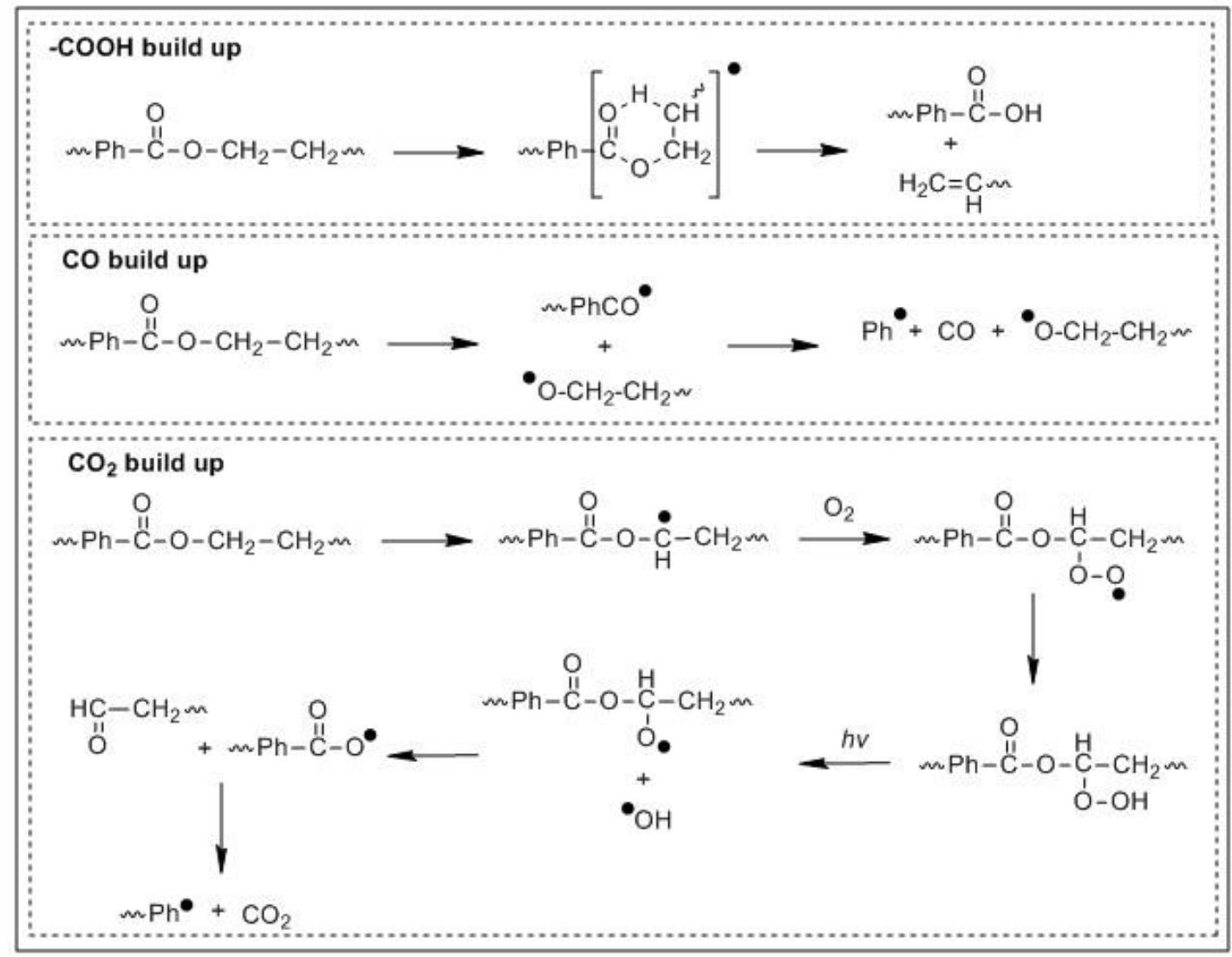

Figure 2. Mechanisms proposed by Day and Wiles for the formation of $-\mathrm{COOH}, \mathrm{CO}$ and $\mathrm{CO}_{2}$ during the photodegradation of PET. ${ }^{5}$

\section{Ultraviolet absorbers}

Ultraviolet absorbers (UVAs) are commercially-available polymer additives that are employed commonly in the polymer industry due to their effectiveness in protecting polymeric materials from UV radiation. They absorb UV light and dissipate the UV energy into harmless heat energy whilst remaining chemically unchanged through a process called excited state intramolecular proton transfer (ESIPT). ${ }^{11-13}$ ESIPT is observed with planar 5- and 6-membered rings that have intramolecular hydrogen bonding (IMHB) between a phenolic hydrogen and a heteroatom. The heteroatom is normally either a nitrogen atom, from 2-(hydroxyphenyl) benzotriazole ${ }^{14,15}$ (BT) or 2-(2-hydroxyphenyl)-1,3,5-tiazine (TA) derivatives, ${ }^{2}$ or an oxygen atom from 2-hydroxybenzophenone (BP) or salicylate derivatives. ${ }^{16}$

Tinuvin 1577 (Figure 3) is one of the most effective UV stabilizers available and is the leading UVA on the market today. ${ }^{17,18}$ This TA derivative is manufactured by BASF and is currently the UVA of choice for DuPont Teijin Films (DTF) as an additive to PET. As well as being a powerful UV screen, Tinuvin 1577 exhibits a robust IMHB, it is resilient to polar environments and it has a low yellowing index. ${ }^{7,9,17,18}$

One major limitation concerning the use of Tinuvin 1577, and essentially all other UVAs, is potential leaching of the stabiliser from the polymer whilst the polymer is in use. The loss of additive over time leads to an increase in the rate of UV-induced degradation and deterioration of key polymer properties, and this is of particular concern for applications where polymers are exposed to high levels of UV radiation. One way in which this can be prevented is by developing and exploiting polymerizable UVAs, where the UVA motif is an integral part of the polymer structure. 


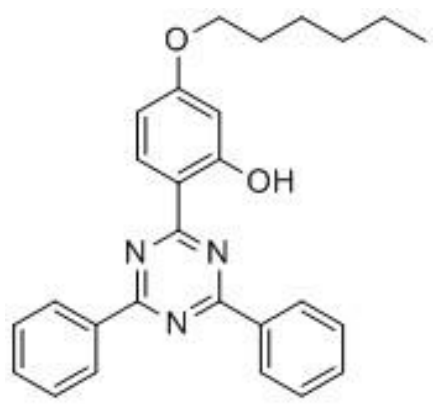

Figure 3. Tinuvin 1577.

There has been extensive work on the preparation of polymerizable UVAs bearing vinyl functionality, especially BP and BT derivatives, where the vinyl functionality allows incorporation of the UVAs into vinyl polymers through free radical polymerization routes. ${ }^{19-24}$ Kramer et al. described the synthesis of TAs with vinyl moieties and the free radical copolymerization of the same with styrene and methyl methacrylate. ${ }^{2,25}$ Recent work by Bojinov and co-workers ${ }^{26-33}$ involved the synthesis of various polymerizable UV stabilizers with a variety of functionalities. Several of Bojinov's compounds contained both a UVA moiety and a photo-antioxidant fragment.

Compared to chain-growth polymerization, there are many fewer examples of UVAs copolymerized via step-growth polymerization processes. Bailey and Vog ${ }^{23,24}$ copolymerized BPs to yield polyamide copolymers and Kulia et al. copolymerized BTs with phenolic moieties in a step-growth polymerization to yield polysulfone and polycarbonate copolymers. ${ }^{15}$ In addition to preventing leaching, Bailey and Vogl reported that polymerized UVAs reduce volatilization of the stabilizing component and that the spectral profiles of the UVAs remained unchanged upon incorporation into the polymers. The focus of the present work was on the production of polymerizable UVAs with structures related to Tinuvin 1577 for the production of polyesters through stepgrowth polymerization routes.

\section{Results and Discussion}

The starting point for the synthetic route to UV absorbing monomers (UVAMs) 10-19 and 24-26 was cyanuric chloride (Figure 4). Cyanuric chloride is an inexpensive building block which has been used extensively in organic synthesis due to its thermally-controlled reactivity, ${ }^{34}$ and the UVAMs targeted were diesters, diols, and monoalcohols for ease of incorporation into polyester syntheses. Grignard and Friedel-Crafts chemistries were employed successfully to build the main chromophore frameworks around the triazine core, with one or more IMHBs being installed. Grignard reagents were used to substitute aryl, biphenyl, fluoro aryl and methoxy aryl moieties onto the triazine ring. Friedel-Crafts chemistry was an effective tool to substitute the second or final chlorine for resorcinol or phloroglucinol. The polymerizable moieties were installed via nucleophilic substitution with an alkyl halide such as 2-bromoethanol, 9-bromo-1-nonanol, 3-chloropropane-1,2-diol and diethyl 2bromo-2-methylmalonate. The phenolic groups in the para positions with respect to the triazine rings present in compounds 5-9, 22 and $\mathbf{2 3}$ were deprotonated under basic conditions to give phenoxide anion nucleophiles which attacked the alkyl halides. The phenolic groups in the ortho positions with respect to the triazine rings were protected by the strong IMHBs and did not partake in nucleophilic substitution reactions. 


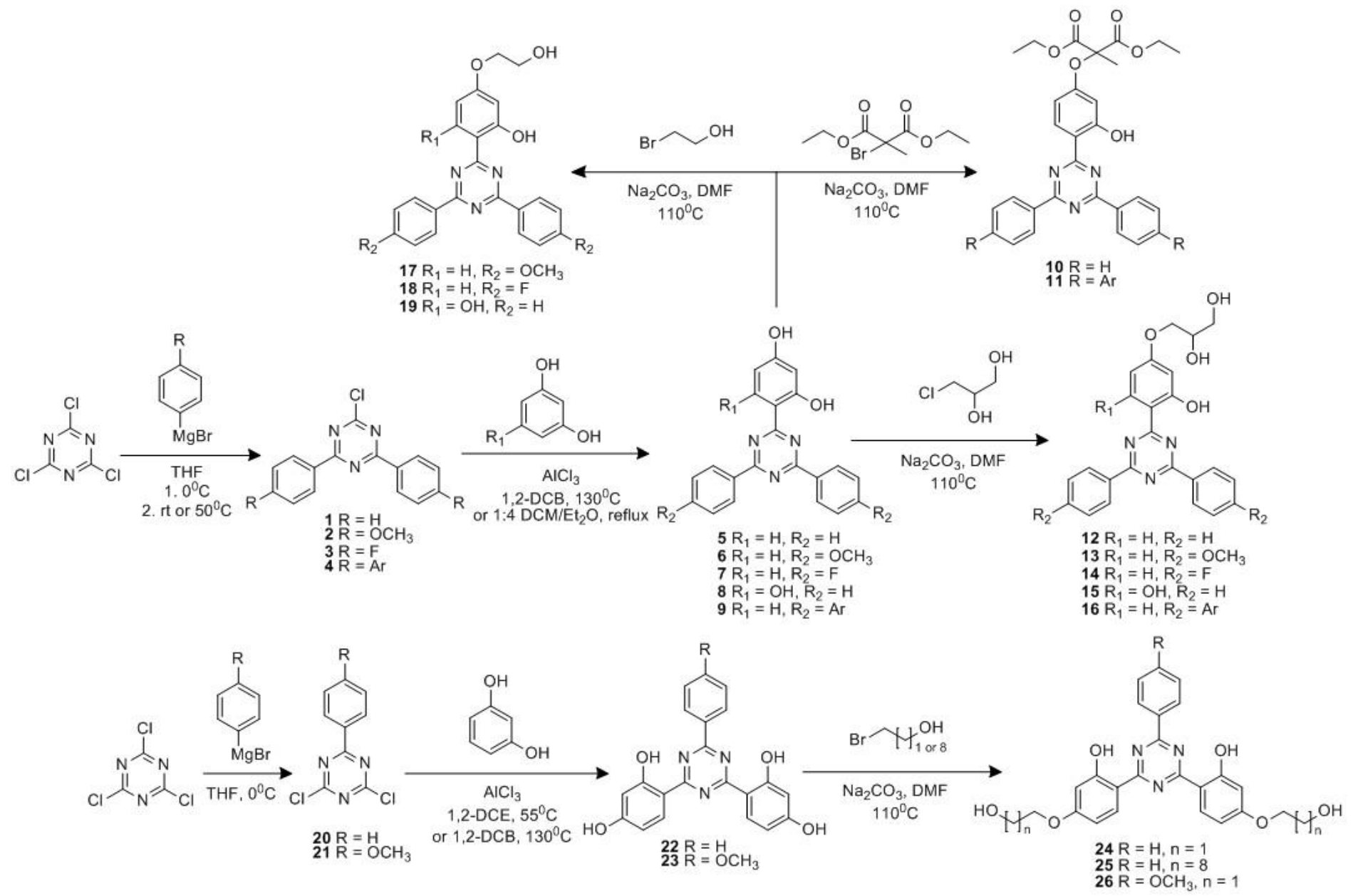

Figure 4. Synthetic routes to UVAMs 10-19 and 24-26.

\section{UV Analysis of UVAMs}

The UV absorbance profiles of the UVAMs were compared against Tinuvin 1577 as a benchmark, and also compared against each other to understand the impact of modifying the chromophore structure on the UV absorbance profile. The UV absorbance profiles of UVAMs 10, 12, 14 and 18 mirrored that of Tinuvin 1577 (Figure 5). This was expected for $\mathbf{1 0}$ and $\mathbf{1 2}$ since the chromophore in these UVAMs is identical to that of the commercial UV additive. This showed that installing the polymerizable moieties on the aliphatic chain of Tinuvin 1577 was an effective way to maintain the attractive UV profile of Tinuvin 1577 whilst rending the UVAs polymerizable. The UV profiles of $\mathbf{1 4}$ and $\mathbf{1 8}$ were nearly identical despite the inductive nature of fluorine. For all of these UVAMs, the higher wavelength band is ascribed to a $\pi-\pi^{*}$ intramolecular charge transfer transition, and the lower wavelength band is attributed to localized $\pi-\pi^{*}$ transitions. 


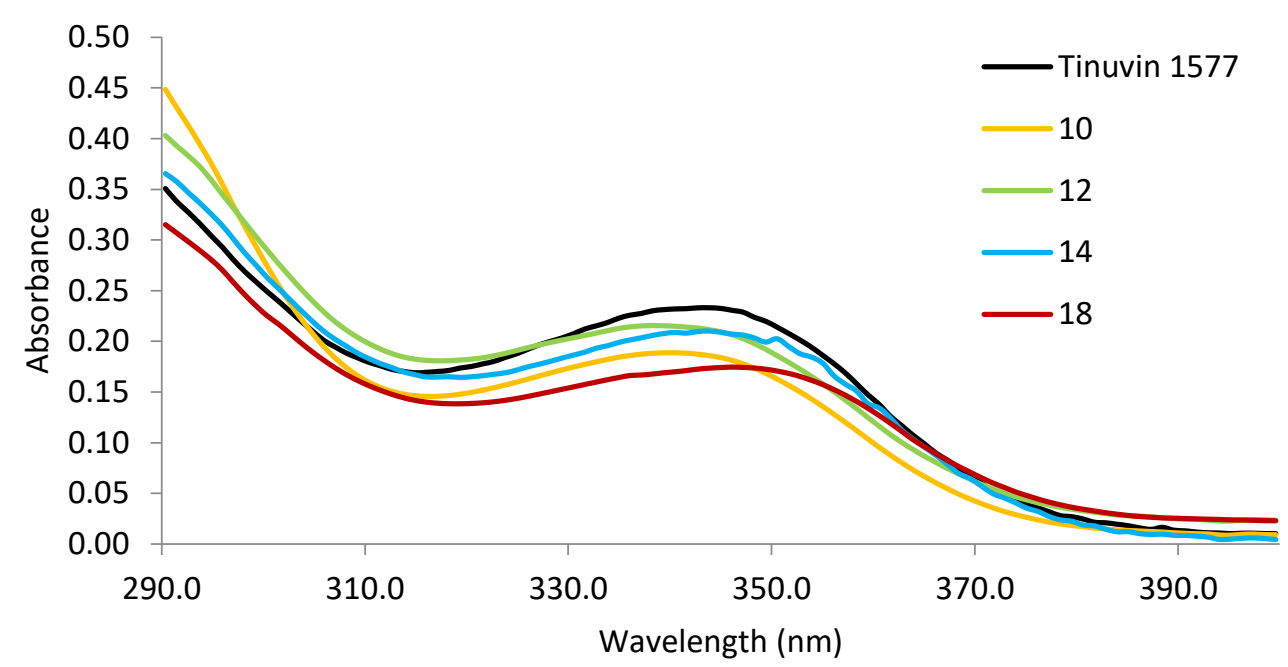

Figure 5. UV absorbance spectra of $0.1 \mathrm{mM}$ solutions of UVAMs 10 (DMSO), 12 (DMSO), 14 (DMSO), 18 (DMSO) and Tinuvin $1577\left(\mathrm{CHCl}_{3}\right)$.

Increasing the conjugation and the number of $\pi$ bonds reduced the energy gap required for electron promotion. A red-shift is commonly observed since reducing the energy needed for excitation increases the wavelength of light. The most conjugated UVAMs, 11 and 16, were the most powerful UV absorbers in this study (Figure 6). The biphenyl groups caused a red-shift in the $\pi-\pi^{*}$ band which overlapped with the $\pi-\pi^{*}$ charge transfer transition. It is important to note that a red-shift into the visible region is undesirable as it produces a brown coloured polymeric product upon copolymerization.

The effect of an electron-donating methoxy group and an electron-withdrawing fluorine group were investigated by comparing the UV absorbance curves of 13 and 14 with Tinuvin 1577 (Figure 7). When comparing the UV spectra of 13 and Tinuvin 1577, the electron-donating methoxy groups caused a red-shift in the $\pi-\pi^{*}$ transitions and increased the molar absorptivity. Keck and co-workers ${ }^{2,35,36}$ have reported that electron-donating functional groups increase the basicity of the nitrogen triazine atoms, which in turn strengthens the IMHB and contributes to the increase in extinction coefficient. The inductive effect of the fluorine atoms had little influence on the UV profile of $\mathbf{1 4}$. In contrast to the methoxy functional groups, the fluorine atoms may marginally weaken the strength of the IMHB. An IMHB that is too weak is susceptible to disruption in polar environments, however the Keck group postulated that an IMHB which is too powerful is unfavorable and can hinder the radiationless deactivation by impeding the twisting vibration between the aryl and heterocyclic moieties. It is therefore important to recognize the potential of decreasing the strength of the IMHB, especially if this is achievable without damaging the UV absorbance of the UVAM.

Comparing the UV curve of 15 to Tinuvin 1577 illustrates the increase in absorbance that is observed when an additional IMHB is introduced. An additional IMHB on the same aryl ring caused a blue-shift and an increase in the molar extinction coefficient of the $\pi-\pi^{*}$ charge transfer transition. Keck ${ }^{2,35,36}$ postulated that this transition relies heavily on the planarity of the orientation and an additional IMHB further reinforces this conformation to give an increase in the molar absorptivity. However, having two IMHBs on the same aryl ring raises questions as to what effect this will have on the ESIPT and radiationless deactivation process. If an IMHB is too strong then this inhibits the twisting vibration and radiationless deactivation, therefore it would be fair to assume that the twisting vibration would be inhibited to a greater extent by an additional IMHB. Furthermore, Shizuka ${ }^{36}$ postulated that the excited molecule undergoes cis-trans isomerization post intramolecular proton 
transfer to prevent reverse intramolecular proton transfer, however one would expect the second IMHB to hinder the $180^{\circ}$ rotation of the triazine-aryl bond. The situation whereby both IMHBs undergo intramolecular proton transfer is unlikely since this would disrupt the aromaticity of the molecule.

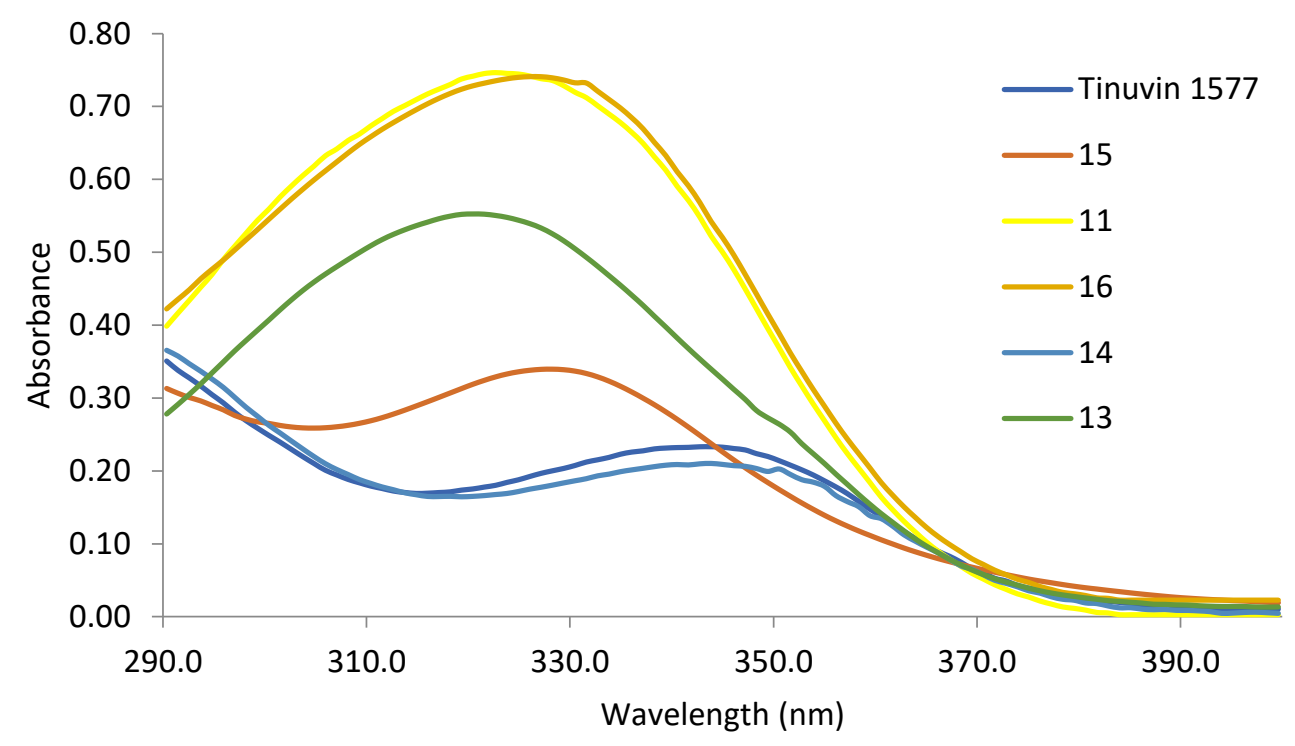

Figure 6. UV absorbance spectra of $0.1 \mathrm{mM}$ solutions of Tinuvin $1577\left(\mathrm{CHCl}_{3}\right), 11\left(\mathrm{CHCl}_{3}\right), 13$ (DMSO), 14 (DMSO), 15 (DMSO) and 16 (DMSO).

UVAMs 24, 25 and 26 had higher molar extinction coefficients than Tinuvin 1577 across the 290-400 nm region (Figure 7). Increasing the number of resorcinyl moieties and the number of IMHBs caused a red-shift in both the $\pi-\pi^{*}$ and charge transfer transitions. A slight red-shift was observed for 25 with long hydroxyalkyl chains in comparison to the UV curve of $\mathbf{2 4}$ which had shorter polymerizable arms. UVAM $\mathbf{2 6}$ had a higher molar absorptivity between 310-350 $\mathrm{nm}$ than $\mathbf{2 4}$ and $\mathbf{2 5}$, with the methoxy group causing a blue-shift in the charge transfer transition and a red-shift in the $\pi-\pi^{*}$ transition resulting in an overlap. Dobashi ${ }^{37,38}$ discovered a clear relationship between the photostabilizing effect and the maximum wavelength of absorption ( $\lambda_{\max }$ ) of the UVA. Dobashi demonstrated that BP and BT ultraviolet absorbers with higher $\lambda_{\max }$ were the superior photostabilizers. If the same is true for TA derivatives and absorbance at longer wavelengths enhances the photostabilizing effect, then this further highlights the application potential of 24, $\mathbf{2 5}$ and $\mathbf{2 6}$. Furthermore, these UVAMs ought to be more adept at preventing the formation of fluorescent by-products during PET degradation, by-products which are formed by deeply penetrating low energy, high wavelength UV light. ${ }^{7,9}$ 


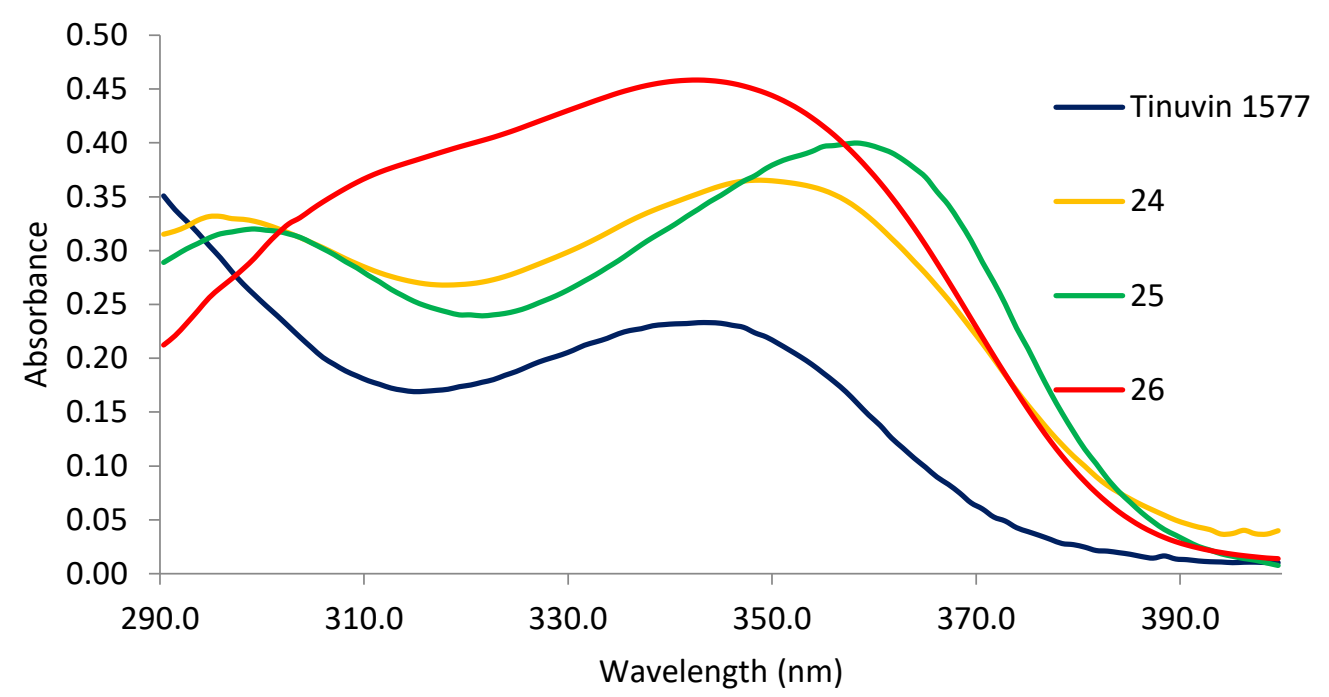

Figure 7. UV absorbance spectra of $0.1 \mathrm{mM}$ solutions of Tinuvin $1577\left(\mathrm{CHCl}_{3}\right), 24$ (DMSO), 25 (DMSO) and 26 $\left(\mathrm{CHCl}_{3}\right)$.

\section{Thermal analysis of UVAMs}

PET and PEI are typically synthesized at $285^{\circ} \mathrm{C}$ in industry, thus the thermal stability of UVAMs is a critical characteristic to ensure that there is minimal loss of active ingredient residing in the polymer and high levels of UV protection. As a useful measure of thermal stability, the onset temperature and weight loss at $300{ }^{\circ} \mathrm{C}$ of the UVAMs were compared to Tinuvin 1577 as a benchmark. Thermogravimetric analysis (TGA) of the UVAMs was carried out in air, with the temperature being increased at a rate of $10{ }^{\circ} \mathrm{C} / \mathrm{min}$. The onset of degradation was calculated by differentiating the percentage weight loss curve.

UVAMs containing propanediol or glycol polymerizable moieties (12-19) showed onset temperature well above $285^{\circ} \mathrm{C}$, however 17 was the only UVAM from this group to display thermal stability superior to Tinuvin 1577 (Table 1). Since the precursors to UVAMs 12-19 were generally more thermally stable than the UVAMs themselves (data not shown), the loss of weight up to $300{ }^{\circ} \mathrm{C}$ could be attributed to the thermal degradation of the polymerizable fragments. This would favour introducing the UVAMs at the beginning of polymerizations and then raising the temperature of a copolymerization gradually, allowing the UVAMs to become incorporated into the polymer chains before degradation can ensue. UVAM 18 exhibited a weight loss of $2.9 \%$ at $120{ }^{\circ} \mathrm{C}$, which was accredited to residual solvent, and this contributed to the $8.6 \%$ weight loss after $300{ }^{\circ} \mathrm{C}$.

Increasing the number of resorcinol moieties and IMHBs increased the thermal stability of the UVAMs. UVAMs 24 and 25 contained two resorcinol moieties and displayed thermal stability superior to Tinuvin 1577, whereas $\mathbf{2 6}$ had properties similar to the commercial additive. UVAM 25 displayed no weight loss after $300{ }^{\circ} \mathrm{C}$, which may be due to the increased stability of long chain polymerizable functional groups. 
Table 1. Thermogravimetric analysis of UVAMs and Tinuvin 1577

\begin{tabular}{ccc}
\hline UVA/UVAM & Weight loss at $300^{\circ} \mathrm{C}(\%)$ & Onset temperature $\left({ }^{\circ} \mathrm{C}\right)$ \\
\hline Tinuvin 1577 & 2.0 & 340 \\
$\mathbf{1 0}$ & 0.8 & 342 \\
$\mathbf{1 1}$ & 1.3 & 326 \\
$\mathbf{1 2}$ & 2.3 & 312 \\
$\mathbf{1 3}$ & 3.6 & 329 \\
$\mathbf{1 4}$ & 3.3 & 346 \\
$\mathbf{1 5}$ & 4.1 & 319 \\
$\mathbf{1 6}$ & 5.7 & 310 \\
$\mathbf{1 7}$ & 1.7 & 339 \\
$\mathbf{1 8}$ & 8.6 & 309 \\
$\mathbf{1 9}$ & 5.6 & 314 \\
$\mathbf{2 4}$ & 1.7 & 388 \\
$\mathbf{2 5}$ & 0 & 411 \\
$\mathbf{2 6}$ & 1.4 & 331 \\
\hline
\end{tabular}

\section{PEI-UVAM Copolymers}

The polyesters prepared during this study were synthesized in a polycondensation rig using bis(2-hydroxyethyl) isophthalate) (BHEI) as the main monomer (Figure 8). UVAMs 10-19 and 24-26 can be incorporated into the monomer feed as comonomers since they have complementary functional groups. BHEI was selected in preference to bis(2-hydroxyethyl) terephthalate) (BHET) as monomer, since the product (PEI) is readily soluble in organic solvents which facilitates both polymer purification and analysis by solution state nuclear magnetic resonance (NMR) and UV spectroscopy, however the synthetic strategy is expected to be generic and can be applied to PET production and the production of other polyesters as well.

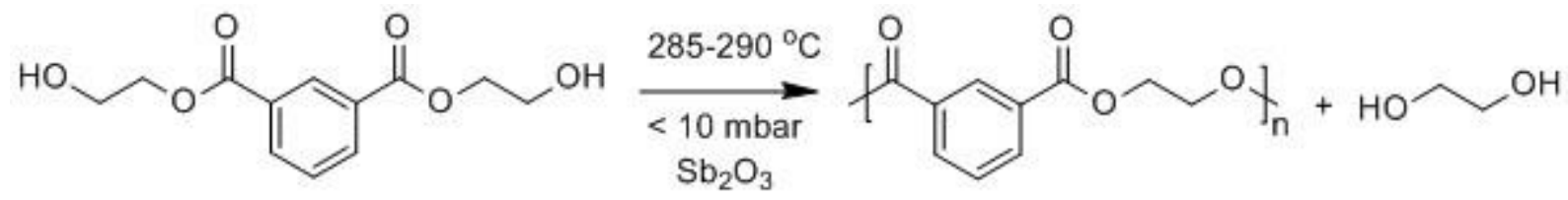

Figure 8. Step-growth polymerization of BHEI to give PEI and ethylene glycol as a by-product.

The trans-esterification reaction generated ethylene glycol which was removed by vacuum to drive the polymerizations to completion. The levels of UVAM used in the monomer feeds to confer UV protection onto the products were typically $1 \mathrm{wt} . \%$. Unlike PET syntheses in the polycondensation rig wherein the stirrer revolution rate drops by 30-40 rpm due to the crystallisation of the PET chains, a significant drop in stirrer rate was not observed during the synthesis of the fully amorphous PEI. Therefore, PEI products were cast after stirring polymerizations at temperatures between $285-290{ }^{\circ} \mathrm{C}$ in vacuo (<10 mbar) for 30 minutes.

The presence of polymerized UVAM residues in the PEl copolymers was confirmed by ${ }^{1} \mathrm{H} N M R$ spectroscopic analysis of the purified copolymers. Furthermore, the level of incorporation of the UVAMs into the copolymers could be calculated by integrating the phenolic resorcinyl protons in the UVAM against the aromatic protons derived from BHEI on the polymer backbone (Table 2). 
There were several circumstances whereby the signals which undergo a change in chemical shift were masked under the PEI signals. Nonetheless, for the copolymerizations involving UVAMs with polymerizable alcohol moieties on short aliphatic chains a change in chemical shift was observed for the phenolic resorcinyl protons. This change was not observed for P1 and P11 whereby the polymerizable moieties were too far from the phenolic resorcinyl protons to induce a change in the chemical shift.

Table 2 Theoretical and calculated values for wt\% and mol\% of UVAMs in copolymers, Tg and molecular weight values of copolymers P1-P12 and PEI

\begin{tabular}{|c|c|c|c|c|c|c|c|c|c|}
\hline \multirow[t]{2}{*}{ Copolymer } & \multirow{2}{*}{$\begin{array}{c}\text { UVAM } \\
\text { Mass } \\
\text { (g) }\end{array}$} & \multirow{2}{*}{$\begin{array}{c}\text { BHEI } \\
\text { Mass (g) }\end{array}$} & \multicolumn{2}{|c|}{ UVAM in feed } & \multicolumn{2}{|c|}{$\begin{array}{l}\text { UVAM in } \\
\text { copolymer }\end{array}$} & \multirow[t]{2}{*}{$\operatorname{Tg}\left({ }^{\circ} \mathrm{C}\right)$} & \multirow[t]{2}{*}{$\overline{M_{w}}$} & \multirow[t]{2}{*}{$\bigoplus$} \\
\hline & & & wt $\%$ & $\mathrm{~mol} \%$ & wt \% & $\mathrm{mol} \%$ & & & \\
\hline PEI & 0 & 100 & 0 & 0 & 0 & 0 & 68.9 & 55,200 & 2.5 \\
\hline P1 Poly(El-co-10) & 0.40 & 39.61 & 1.00 & 0.50 & 0.90 & 0.34 & 66.3 & 43,100 & 2.5 \\
\hline P2 Poly(EI-co-12) & 0.40 & 39.60 & 1.00 & 0.62 & 0.91 & 0.42 & 67.1 & 38,500 & 2.7 \\
\hline P3 Poly(EI-co-13) & 0.40 & 39.70 & 1.00 & 0.54 & 0.89 & 0.36 & 65.8 & 55,000 & 3.9 \\
\hline P4 Poly(El-co-14) & 0.40 & 39.60 & 1.00 & 0.57 & 1.31 & 0.56 & 66.6 & 51,000 & 4.3 \\
\hline P5 Poly(El-co-15) & 0.40 & 40.10 & 1.00 & 0.60 & 0.80 & 0.36 & 67.5 & 54,200 & 3.4 \\
\hline P6 Poly(El-co-16) & 0.40 & 39.70 & 1.00 & 0.45 & 0.94 & 0.32 & 66.8 & 33,300 & 2.7 \\
\hline P7 Poly(El-co-17) & 0.40 & 39.50 & 1.00 & 0.56 & 0.97 & 0.41 & 66.1 & 44,900 & 3.5 \\
\hline P8 Poly(El-co-18) & 0.40 & 39.50 & 1.00 & 0.61 & 0.88 & 0.40 & 66.1 & 21,000 & 2.6 \\
\hline P9 Poly(El-co-19) & 0.70 & 69.30 & 1.00 & 0.65 & 0.73 & 0.34 & 65.1 & 23,700 & 3.0 \\
\hline P10 Poly(El-co-24) & 0.50 & 49.50 & 1.00 & 0.57 & 0.67 & 0.28 & 68.3 & 107,000 & 3.8 \\
\hline P11 Poly(El-co-25) & 0.93 & 95.00 & 0.97 & 0.38 & 0.51 & 0.15 & 57.6 & 45,700 & 2.9 \\
\hline P12 Poly(EI-co-26) & 0.40 & 39.60 & 1.00 & 0.52 & 0.51 & 0.20 & 69.2 & 67,000 & 3.7 \\
\hline
\end{tabular}

Differential scanning calorimetry (DSC) analysis of the copolymers revealed marginally lower glass transition temperatures ( $\mathrm{Tg}$ ) for the products compared to that of PEI homopolymer, with the exception of P12 where there was a slight increase in $\mathrm{Tg}$ (Table 2). This is unsurprising given the low levels of UVAMs used in the copolymerizations. A melting transition was not observed for the copolymers since PEI is amorphous.

The copolymers exhibiting the lowest weight average molecular weights were P8 and P9 which contained monofunctional UVAMs which act as chain stoppers (Table 2). The copolymerization of the monofunctional 17 did yield a copolymer with a high $\overline{M_{w}}$ of 44,900 , however the bifunctional derivative of 17, UVAM 13, was copolymerized at similar levels and generated a copolymer with a higher $\overline{M_{w}}$ still $(55,000)$.

\section{UV Analysis of UVAM-Containing Copolymers}

UVAMs with the same chromophore as Tinuvin 1577 were copolymerized with BHEI to give $\mathbf{P} \mathbf{1}$ and $\mathbf{P 2}$, and the copolymers exhibited similar UV profiles with $\lambda_{\max }$ in the region of 340-343 nm (Figure 9). The UV spectra showed no protrusion into the visible region, however absorbance levels between 370-400 nm were very weak. Work carried out by Fechine ${ }^{9}$ demonstrated that UV light above $340 \mathrm{~nm}$ was responsible for the formation of 
fluorescent mono-hydroxyl species. Therefore, UVAMs 10 and 12 would be less effective in preventing the formation of fluorescent products from photodegradation at long wavelengths.

UVAMs 13, 15 and 16 had chromophores different to that of Tinuvin 1577, and the copolymers P3, P5 and P6 displayed superior molar absorptivity at wavelengths $\mathbf{2 9 0}-400 \mathrm{~nm}$ in comparison to P1 and P2. Despite the fluorinated aryl rings, 14 mimicked the UV profile of Tinuvin 1577, and for that reason the copolymer P4 had an identical UV profile to that of P1 and P2. The copolymer with the highest molar absorptivity was P3, which contained 0.36 mol \% of polymerized UVAM 13, surprisingly outperforming P6 which contained 0.30 mol \% of the more potent UVAM 16. Wavelengths between $310-315 \mathrm{~nm}$ are critical for polymer degradation, leading to the production of $\mathrm{COOH}$ end groups in the bulk and front and rear surfaces of polymer films. ${ }^{4,39}$ Therefore UVAMs 13 and 16 possess great potential for combating UV degradation, specifically chain scissions and the formation of acid end groups. No significant red- or blue-shifts were observed when comparing the $\lambda_{\max }$ of P3P6 to that of the free monomers. UVAM 15 contained two IMHBs and the UV spectrum of P5 showed an increased absorbance at wavelengths above $365 \mathrm{~nm}$ in comparison to P3, P4 and P6. This shows that $\mathbf{1 5}$ is more adept at protecting the polymer from the formation of fluorescent mono-/di-hydroxyterephthalate by-products caused by deeply penetrating low energy UV light.

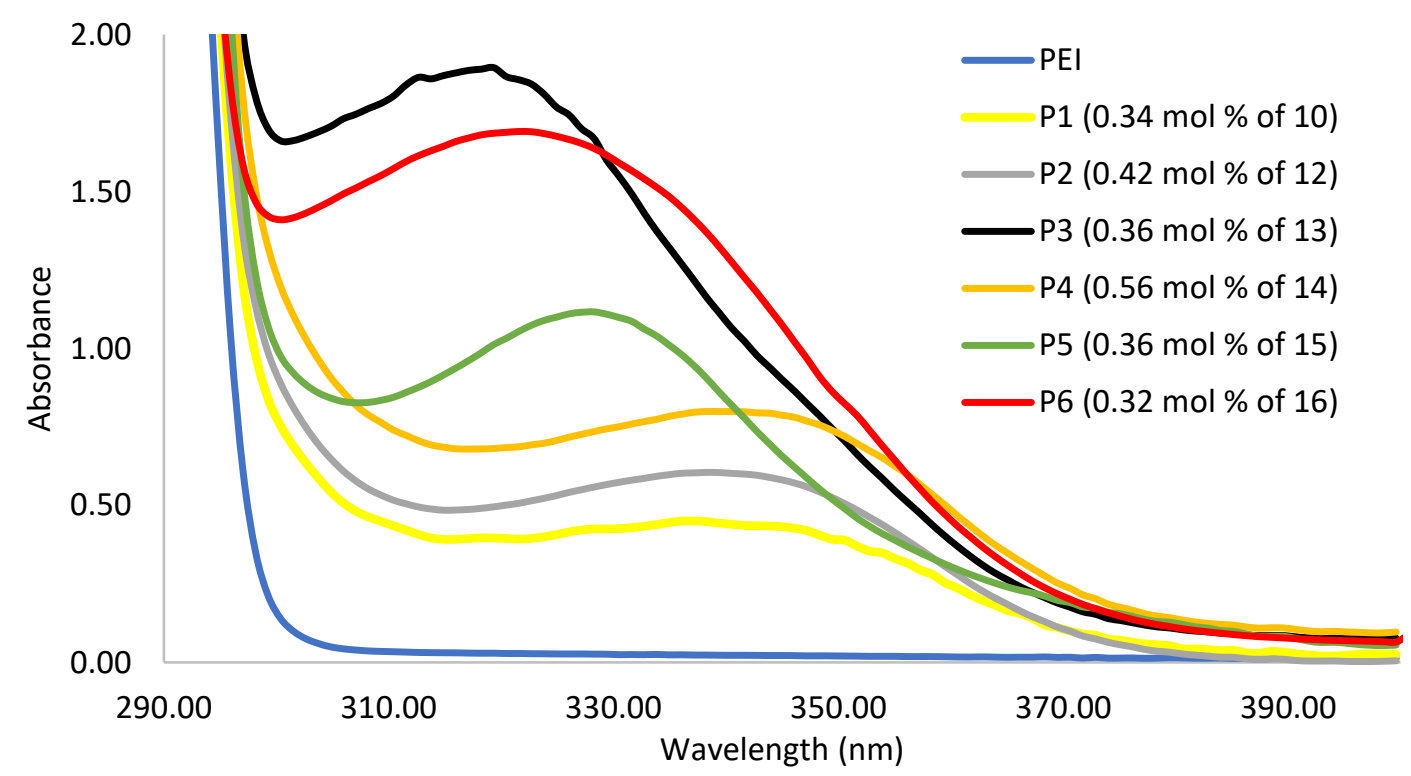

Figure 9. UV absorption spectra of $10 \mathrm{mg} / \mathrm{mL}$ solutions of copolymers $\mathbf{P 1 - P 6}$ and $\mathrm{PEI}$ in $\mathrm{CHCl}_{3}$.

At 1 wt \% loadings of UVAM $\mathbf{2 4}$ and $\mathbf{2 5}$ in the monomer feed, the former showed a considerably stronger molar absorptivity after copolymerization and a $10 \mathrm{~nm}$ blue-shift of the $\lambda_{\max }$ was observed upon copolymerization of UVAM 25 (Figure 10). UVAM 26 had a higher molar absorptivity in comparison to the less conjugated 24 and 25, which resulted in copolymer P12 exhibiting a higher molar extinction coefficient in comparison to P10 and P11. Taking into consideration all the PEl copolymers in this study, P5, P10, P11 and P12 showed the strongest coverage at wavelengths above $355 \mathrm{~nm}$. The copolymers reported in Figure 10 contained UVAMs with two IMHBs which enhanced coverage at longer UV wavelengths, and $\mathbf{2 4}$ was identified as the UVAM which provided the highest molar absorptivity at longer wavelengths. Therefore 15, 24, 25 and 26 seem to be the most efficient UVAMs for preventing the formation of fluorescent materials during photodegradation. 


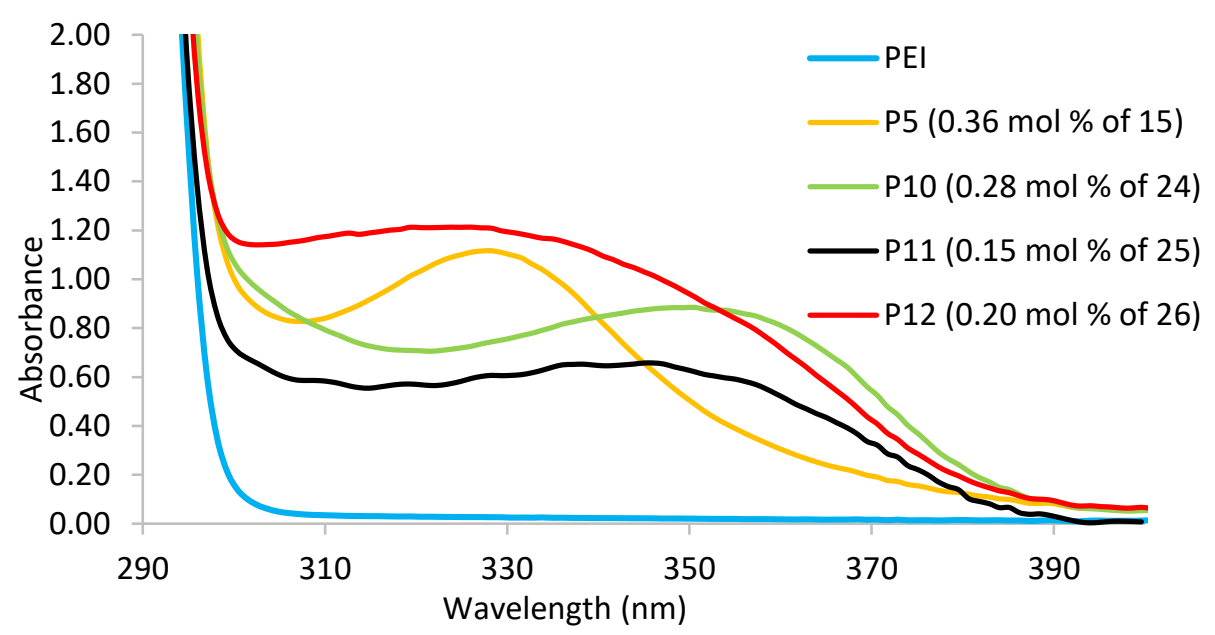

Figure 10. UV absorbance spectra of $10 \mathrm{mg} / \mathrm{mL}$ solutions of copolymers $\mathbf{P} 5, \mathbf{P} 10, \mathbf{P} 11, \mathbf{P} 12$ and $\mathrm{PEI}$ in $\mathrm{CHCl}_{3}$.

The UV absorbance spectra of copolymers containing bifunctional UVAMs displayed higher molar extinction coefficients than the copolymers containing their monofunctional counterparts (Figure 11). Bifunctional 15 showed increased UV absorbance compared to the monofunctional 19, even although the level of incorporation measured by ${ }^{1} \mathrm{H}$ NMR for both monomers was similar. When comparing $\mathbf{P 4}$ and P8, there was a significant difference in the intensity of the UV curves and the level of incorporation as judged from the ${ }^{1} \mathrm{H}$ NMR spectra, with the bifunctional UVAM 14 showing much higher levels of incorporation than the monofunctional UVAM 18. One thing to consider for UVAMs 12-16 is that the reactivity of the polymerizable hydroxyl groups of the propanediol moiety are not identical, with one being a primary alcohol and the other a secondary alcohol. It can be predicted that even higher levels of incorporation and higher molar absorptivity could be gained from using bifunctional UVAMs bearing two primary alcohol functional groups.

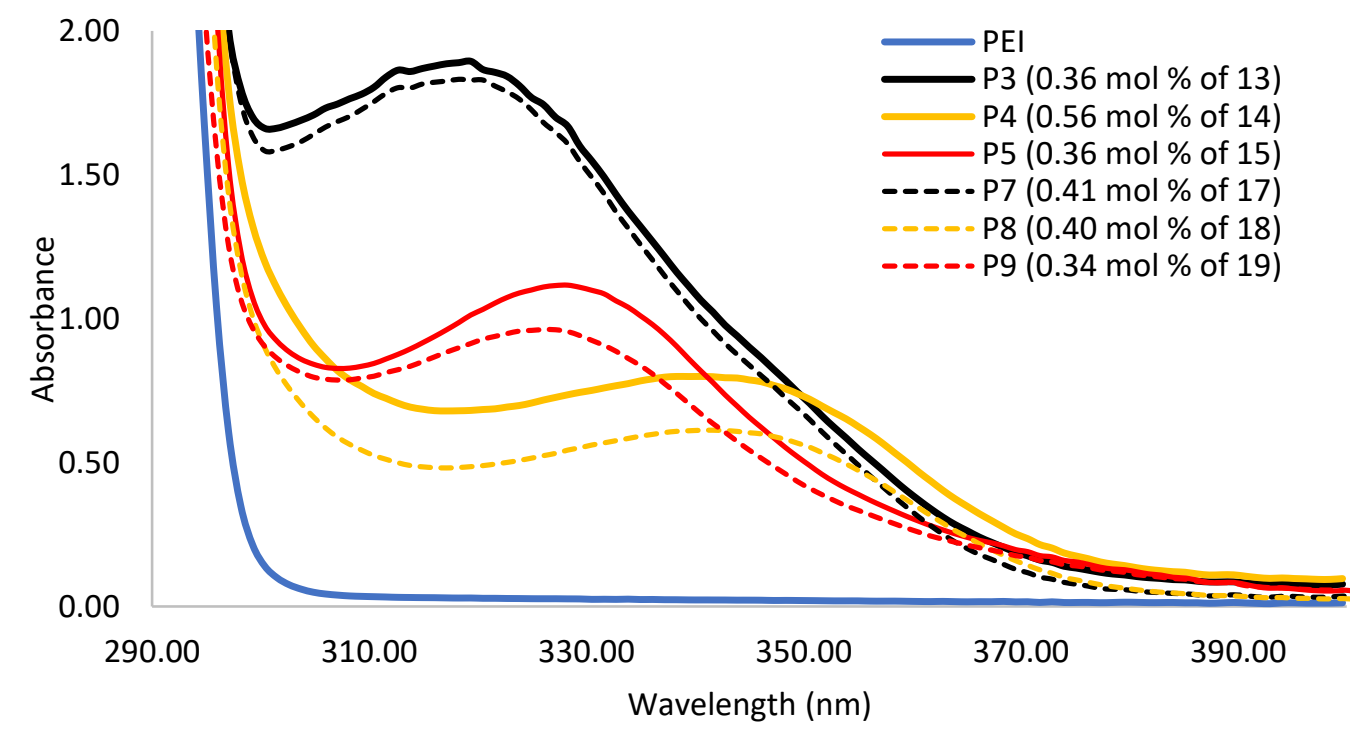

Figure 11. UV absorption spectra of $10 \mathrm{mg} / \mathrm{mL}$ solutions of copolymers $\mathbf{P 3}, \mathbf{P 4}, \mathbf{P 5}, \mathbf{P 7}, \mathbf{P} 8, \mathbf{P 9}$ and $\mathrm{PEl}$ in $\mathrm{CHCl}_{3}$.

At 1 wt \% loadings of UVAM 24 and 25 in the monomer feed, the former showed a considerably higher molar absorptivity after copolymerization and a $10 \mathrm{~nm}$ blue-shift of the $\lambda_{\max }$ was observed upon 
copolymerization of UVAM 25 (Figure 10). UVAM 26 had a higher molar absorptivity in comparison to the less conjugated 24 and 25, which resulted in copolymer P12 exhibiting a higher molar extinction coefficient in comparison to $\mathbf{P} 10$ and $\mathbf{P 1 1}$. Taking into consideration all the PEl copolymers in this study, P5, P10, P11 and P12 showed the strongest coverage at wavelengths above $355 \mathrm{~nm}$. The copolymers reported in Figure 10 contained UVAMs with two IMHBs which enhanced coverage at longer UV wavelengths, and $\mathbf{2 4}$ was identified as the UVAM which provided the highest molar absorptivity at longer wavelengths. Therefore 15, 24, 25 and 26 are expected to be the most efficient UVAMs for preventing the formation of fluorescent materials during photodegradation.

\section{Conclusions}

A library of novel ultraviolet absorber monomers (UVAMs) for use in step-growth polymerizations have been synthesized using cyanuric chloride as a synthetic starting point. Grignard and Friedel-Crafts chemistries were employed to construct the core chromophore structures, with the structures of the UVAMs being based on the chromophore of the commercial UVA Tinuvin 1577. A wider and stronger UV absorbance was generally observed when increasing the number of IMHBs, electron density and conjugation of the chromophores. The UVAMs exhibited more than satisfactory thermal stability for polyester synthesis via step-growth polymerization and for polyester processing, and it ought not to be over-looked that these novel UVAMs are potentially interesting low molar mass UV stabilizers in their own right.

UVAMs were incorporated successfully into PEI through copolymerization. ${ }^{1} \mathrm{H} N M R$ and UV spectroscopic analysis of the copolymers showed incorporation of the UVAMs, with only low levels of UVAM being required to change dramatically the UV absorption profiles of the copolymers. The majority of copolymerized UVAMs displayed no blue- or red-shifts, which indicated that the UV profiles of most of the monomers were unaffected by copolymerization and that the IMHBs were present and correct in the copolymers. Overall, a new family of UVAMs has been set in place, and the polyesters derived from these UVAMs are expected to have enhanced resistance to UV degradation compared to the parent polymers.

\section{Experimental Section}

General. BHEl was provided by DuPont Teijin Films (DTF). All other chemicals used were of analytical reagent grade and were commercially available from Aldrich, Fisher or VWR. All solvents used in this study did not require further purification. Anhydrous THF, diethyl ether, hexane and DCM were obtained from an SPS solvent drying system. The solvents and reagents were used as received without any further purification unless indicated otherwise.

A Perkin Elmer Spectrum One Fourier Transform Infrared (FT-IR) spectrometer was used to record FT-IR spectra. The spectra were recorded using Attenuated Total Reflectance (ATR) within the range 400 to $4000 \mathrm{~cm}^{-1}$. NMR spectra were recorded on Bruker DPX 400 and DRX 500 instruments in the NMR Laboratory at the University of Strathclyde, for ${ }^{1} \mathrm{H},{ }^{13} \mathrm{C}$ and ${ }^{19} \mathrm{~F}$ nuclei. The chemical shifts $(\delta)$ are quoted in part per million (ppm), relative to the residual proton resonances of the solvent, and coupling constants (J values) in $\mathrm{Hz}$. Multiplicities for the ${ }^{1} \mathrm{H}$ NMR spectra are abbreviated as: $s$, singlet; $d$, doublet; $t$, triplet; $q$, quartet; $m$, multiplet. In cases where superimposition of signals arose, the signals were reported as a multiplet $(\mathrm{m}) . \mathrm{CDCl}_{3}$ and $d_{6}$-DMSO were used as NMR solvents. High resolution mass spectrometry (HRMS) was carried out in the Strathclyde Institute of 
Pharmacy and Biomedical Sciences (SIPBS). HRMS was performed using a Thermo Scientific-Exactive Orbitrap Mass Spectrometer. Methanol was used as the solvent and the scan range was 75-1200 $\mathrm{m} / \mathrm{z}$. Gas chromatography mass spectrometry (GC-MS) was carried out using an Agilent Technologies 7890A GCMS with a RESTEK RXi-5Sil MS column. Samples were dissolved in $\mathrm{CHCl}_{3}$ and helium was used as the gas carrier at a flow rate of $1 \mathrm{~mL} / \mathrm{min}$. The ions were produced by electron ionization (EI) using a nitrogen laser at $337 \mathrm{~nm}$. UVVisible absorption spectra were acquired using a Photonics CCD array UV-Vis spectrophotometer with a $1 \mathrm{~mm}$ pathlength quartz cell. DMSO and $\mathrm{CHCl}_{3}$ were used as solvents and the scan range was $290-500 \mathrm{~nm}$. Thermogravimetric analysis of UVAMs was performed using a Perkin Elmer TGA 7. Approximately $10 \mathrm{mg}$ of sample was heated in air at a rate of $10{ }^{\circ} \mathrm{C} / \mathrm{min}$. from $40{ }^{\circ} \mathrm{C}$ to $500{ }^{\circ} \mathrm{C}$. Uncorrected melting points were determined in capillary tubes using a Gallenkamp Griffin Melting Point Apparatus. DSC analysis of polymer samples was carried out at DTF using a 6000 Enhanced Single-Furnace DSC. The samples were heated from -20 ${ }^{\circ} \mathrm{C}$ to $310^{\circ}$ at a rate of $20^{\circ} \mathrm{C} / \mathrm{min}$., cooled back to $-20^{\circ} \mathrm{C}$ at a rate of $50{ }^{\circ} \mathrm{C} / \mathrm{min}$. and then reheated to $310{ }^{\circ} \mathrm{C}$ at a rate of $20^{\circ} \mathrm{C} / \mathrm{min}$. Molecular weight determination of polymers was carried out by Intertek using a Viscotek GPC Max instrument with refractive index detection. The samples were dissolved in hexafluoroisopropanol (HFIP) and passed through a PLgel HFIP Gel Column at a flow rate of $0.7 \mathrm{~mL} / \mathrm{min}$ at $40{ }^{\circ} \mathrm{C}$.

2-Chloro-4,6-diphenyl-1,3,5-triazine (1). $1 \mathrm{M}$ Phenylmagnesium bromide in THF (250 mL, $0.25 \mathrm{~mol})$ was added dropwise to a solution of cyanuric chloride $(20.00 \mathrm{~g}, 0.11 \mathrm{~mol})$ in anhydrous THF $(300 \mathrm{~mL})$ under nitrogen, whilst maintaining the temperature at $0{ }^{\circ} \mathrm{C}$. Once the addition was complete, the mixture was stirred at room temperature for 16 hours and poured into cold $10 \% \mathrm{v} / \mathrm{v}$ aqueous $\mathrm{HCl}(200 \mathrm{~mL})$. The THF was removed under reduced pressure and the organic product was extracted with $\mathrm{CHCl}_{3}(3 \times 150 \mathrm{~mL})$. The organic layer was washed with water $(2 \times 150 \mathrm{~mL})$ and brine $(100 \mathrm{~mL})$, dried over anhydrous sodium sulfate and the solvent removed under reduced pressure to give a purple/red coloured solid. The crude product was purified by grinding into a fine powder, suspending and washing with $\mathrm{MeOH}(3 \times 100 \mathrm{~mL})$. The product was dried at $70{ }^{\circ} \mathrm{C}$ in vacuo $(60 \mathrm{mbar})$ to yield $19.07 \mathrm{~g}(67 \%)$ of 1 as a white powder. HRMS: found $m / z 268.0635(\mathrm{M}+\mathrm{H})^{+}$; calculated $\mathrm{m} / \mathrm{z} 268.0642$. M. pt. expected: $139-140{ }^{\circ} \mathrm{C} ;{ }^{40}$ found: $137-139{ }^{\circ} \mathrm{C}$. FT-IR (ATR): $\bar{v} / \mathrm{cm}^{-1}: 3049,1537,1490 .{ }^{1} \mathrm{H} \mathrm{NMR}(500 \mathrm{MHz}$,

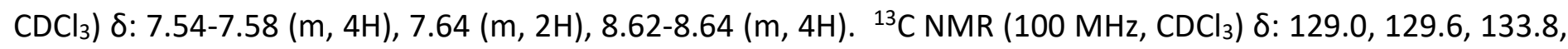
134.6, 172.4, 173.6

2-Chloro-4,6-bis(4-methoxyphenyl)-1,3,5-triazine (2). 0.5 M 4-Methoxyphenylmagnesium bromide in THF (45 $\mathrm{mL}, 25.00 \mathrm{mmol}$ ) was added to a stirred solution of cyanuric chloride ( $1.84 \mathrm{~g}, 10.00 \mathrm{mmol}$ ) in anhydrous THF (25 $\mathrm{mL}$ ) under nitrogen, whilst maintaining the temperature at $0{ }^{\circ} \mathrm{C}$. Once the addition was complete, the reaction mixture was stirred at room temperature for 16 hours and poured into cold $10 \% \mathrm{v} / \mathrm{v}$ aqueous $\mathrm{HCl}(100 \mathrm{~mL})$. The THF was removed under reduced pressure and the organic product was extracted with $\mathrm{CHCl}_{3}(2 \times 50 \mathrm{~mL})$. The organic layer was washed with water $(2 \times 100 \mathrm{~mL})$ and brine $(50 \mathrm{~mL})$, dried over anhydrous sodium sulfate and the solvent removed under reduced pressure. The crude solid was purified by grinding into a fine powder, suspending and washing with $\mathrm{MeOH}(3 \times 100 \mathrm{~mL})$. The white coloured product was dried at $40{ }^{\circ} \mathrm{C}$ in vacuo $(60$ mbar) to yield 2 (1.57 g, 48\%). HRMS: found $\mathrm{m} / \mathrm{z} 328.0848[\mathrm{M}+\mathrm{H}]^{+}$; calculated $\mathrm{m} / \mathrm{z} 328.0847$. M. pt. expected: 195-197 ${ }^{\circ} \mathrm{C} ;{ }^{41}$ found: $194-195^{\circ} \mathrm{C}$. FT-IR (ATR): $\bar{v} / \mathrm{cm}^{-1}: 3017,2973,2935,1516,1241 .{ }^{1} \mathrm{H} \mathrm{NMR}\left(500 \mathrm{MHz} \mathrm{CDCl}_{3}\right)$

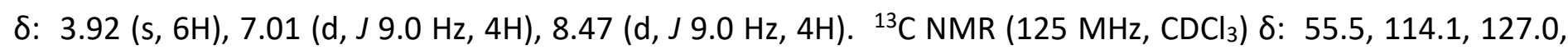
131.4, 164.1, 171.7, 172.6.

2-Chloro-4,6-bis(4-fluorophenyl)-1,3,5-triazine (3). $1 \mathrm{M}$ 4-Fluorophenylmagnesium bromide in THF (30 mL, $0.03 \mathrm{~mol}$ ) was added dropwise to a stirred solution of cyanuric chloride (1.84 g, $0.01 \mathrm{~mol}$ ) in anhydrous THF (30 $\mathrm{mL}$ ) under nitrogen, whilst maintaining the temperature at $0{ }^{\circ} \mathrm{C}$. Once the addition was complete, the mixture was stirred for 16 hours at room temperature and then poured into cold $10 \% \mathrm{v} / \mathrm{v}$ aqueous $\mathrm{HCl}(50 \mathrm{~mL})$. The THF was removed under reduced pressure and the organic product was extracted with $\mathrm{CHCl}_{3}(2 \times 50 \mathrm{~mL})$. The organic 
layer was washed with water $(2 \times 50 \mathrm{~mL})$ and brine $(50 \mathrm{~mL})$, dried over anhydrous sodium sulfate and the solvent removed under reduced pressure. The crude solid was purified by grinding into a fine powder, suspending and washing with $\mathrm{MeOH}(3 \times 100 \mathrm{~mL})$. The white coloured product was dried at $40{ }^{\circ} \mathrm{C}$ in vacuo $(60 \mathrm{mbar})$ to yield 3 (1.52 g, 50\%). HRMS: found $\mathrm{m} / \mathrm{z} 304.0448[\mathrm{M}+\mathrm{H}]^{+}$; calculated $\mathrm{m} / \mathrm{z} 304.0448$. M. pt. expected: $177-180{ }^{\circ} \mathrm{C} ;{ }^{42}$ found: $176-178{ }^{\circ} \mathrm{C}$. FT-IR (ATR): $\bar{v} / \mathrm{cm}^{-1}: 3116,3072,1531,1492 .{ }^{1} \mathrm{H} N M R\left(400 \mathrm{MHz}, \mathrm{CDCl}_{3}\right) \delta: 7.19-7.26(\mathrm{~m}$,

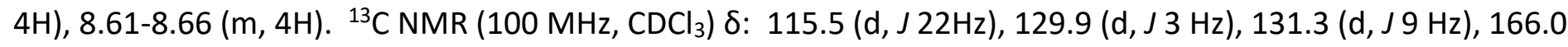
(d, J $254 \mathrm{~Hz}), 171.6,171.8 .{ }^{19} \mathrm{~F} \mathrm{NMR}\left(400 \mathrm{MHz} \mathrm{CDCl}_{3}\right) \delta:-104.7(\mathrm{~m}, 2 \mathrm{~F})$.

2,4-Bis([1,1'-biphenyl]-4-yl)-6-chloro-1,3,5-triazine (4). 0.5 M 4-Biphenylmagnesium bromide in THF (50.00 mL, $25.00 \mathrm{mmol}$ ) was added dropwise to a stirred solution of cyanuric chloride $(1.53 \mathrm{~g}, 8.33 \mathrm{mmol})$ in anhydrous THF $(100 \mathrm{~mL})$ under nitrogen, whilst maintaining the temperature at $0{ }^{\circ} \mathrm{C}$. Once the addition was complete, the mixture was stirred for 16 hours at $50{ }^{\circ} \mathrm{C}$ and poured into $10 \% \mathrm{v} / \mathrm{v}$ aqueous $\mathrm{HCl}(100 \mathrm{~mL})$. The THF was removed under reduced pressure and the organic product was extracted with $\mathrm{CHCl}_{3}(2 \times 50 \mathrm{~mL})$. The organic layer was washed with water $(2 \times 50 \mathrm{~mL})$ and brine $(50 \mathrm{~mL})$, and dried over anhydrous sodium sulfate. The solvent was removed under reduced pressure and purified by grinding into a fine powder, suspending and washing with $\mathrm{MeOH}(3 \times 100 \mathrm{~mL})$. The white coloured powder was dried at $70{ }^{\circ} \mathrm{C}$ in vacuo $(60 \mathrm{mbar})$ to yield $4(2.00 \mathrm{~g}, 57 \%)$. HRMS: found $\mathrm{m} / \mathrm{z} 420.1263[\mathrm{M}+\mathrm{H}]^{+}$; calculated $\mathrm{m} / z$ 420.1262. M. pt. found: $164-167{ }^{\circ} \mathrm{C}$. FT-IR (ATR): $\bar{v} / \mathrm{cm}^{-1}$ : 3035, 3034, 1526, 1489. ${ }^{1} \mathrm{H}$ NMR $\left(400 \mathrm{MHz}, \mathrm{CDCl}_{3}\right)$ 8: 7.43-7.47 (m, 2H), 7.51-7.54 (m, 4H), 7.71-7.73 (m, 4H),

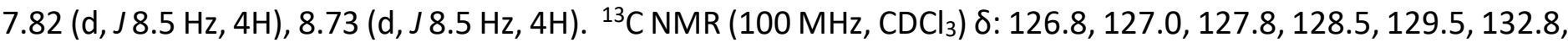
$139.5,145.8,171.6,172.6$.

4-(4,6-Diphenyl-1,3,5-triazin-2-yl)benzene-1,3-diol (5). $\mathrm{AlCl}_{3}(1.91 \mathrm{~g}, 14.60 \mathrm{mmol}$ ) was added to a suspension of 2-chloro-4,6-diphenyl-1,3,5-triazine $1(3.00 \mathrm{~g}, 11.20 \mathrm{mmol}$ ) and resorcinol (1.49 $\mathrm{g}, 13.50 \mathrm{mmol})$ in 1,2dichlorobenzene $\left(250 \mathrm{~mL}\right.$ ) and stirred at $130{ }^{\circ} \mathrm{C}$ for 16 hours under nitrogen. The mixture was cooled to room temperature and quenched with $10 \% \mathrm{v} / \mathrm{v}$ aqueous $\mathrm{HCl}(150 \mathrm{~mL})$. After stirring at room temperature for 1 hour, the red coloured precipitate was collected by filtration, washed with water $(150 \mathrm{~mL})$ and dried at $70{ }^{\circ} \mathrm{C}$ in vacuo (60 mbar). No further purification was required and the red coloured crude product 5 ( $3.03 \mathrm{~g}, 78 \%)$ was used in the subsequent step. M. pt. Found: $272{ }^{\circ} \mathrm{C}$. HRMS: found $m / z 342.1235(\mathrm{M}+\mathrm{H})^{+}$; calculated $\mathrm{m} / z$ 342.1237. UV $\lambda_{\max }\left(0.1 \mathrm{mM}\right.$ in DMSO): $343 \mathrm{~nm}\left(\varepsilon=24,000 \mathrm{~cm}^{-1} \mathrm{M}^{-1}\right)$. FT-IR (ATR): $\bar{v} / \mathrm{cm}^{-1}: 3150-3400,3057,1508,1519,1504$. ${ }^{1} \mathrm{H}$ NMR $\left(500 \mathrm{MHz}, \mathrm{DMSO}-d_{6}\right) \delta: 6.38(\mathrm{~d}, J 2.0 \mathrm{~Hz}, 1 \mathrm{H}), 6.53(\mathrm{dd}, J$ 9.0, $2.0 \mathrm{~Hz}, 1 \mathrm{H}), 7.63-7.65(\mathrm{~m}, 4 \mathrm{H}) 7.69-7.72$ $(\mathrm{m}, 2 \mathrm{H}), 8.48(\mathrm{~d}, J 9.0 \mathrm{~Hz}, 1 \mathrm{H}), 8.52-8.54(\mathrm{~m}, 4 \mathrm{H}), 10.48(\mathrm{~s}, 1 \mathrm{H}), 13.22(\mathrm{~s}, 1 \mathrm{H}) .{ }^{13} \mathrm{C} \mathrm{NMR}\left(100 \mathrm{MHz}, \mathrm{DMSO}-d_{6}\right) \delta$ : $103.5,109.36,109.44,129.0,129.5,132.0,133.7,135.2,164.2,164.8,170.0,171.1$.

4-(4,6-Bis(4-methoxyphenyl)-1,3,5-triazin-2-yl)benzene-1,3-diol (6). $\mathrm{AlCl}_{3}(0.12 \mathrm{~g}, 9.2 \mathrm{mmol}$ ) was added to a suspension of 2-chloro-4,6-bis(4-methoxyphenyl)-1,3,5-triazine $2(0.25 \mathrm{~g}, 0.76 \mathrm{mmol})$ and resorcinol $(0.10 \mathrm{~g}$, $0.92 \mathrm{mmol})$ in 1,2-dichlorobenzene $(10 \mathrm{~mL})$ and the reaction mixture was stirred at $130{ }^{\circ} \mathrm{C}$ for 16 hours under nitrogen. The reaction mixture was cooled to room temperature and $10 \% \mathrm{v} / \mathrm{v}$ aqueous $\mathrm{HCl}(30 \mathrm{~mL})$. The suspension was spun in a centrifuge at $1000 \mathrm{rpm}$ for $5 \mathrm{~min}$. and the supernatant was removed. The solid residue was collected by filtration, washed with water $(100 \mathrm{~mL})$ and dried at $70{ }^{\circ} \mathrm{C}$ in vacuo $(60 \mathrm{mbar})$. No further purification was necessary and the red coloured crude solid $6(0.33 \mathrm{~g}, 90 \%)$ was used in the subsequent step. HRMS: found $\mathrm{m} / \mathrm{z} 400.1307(\mathrm{M}-\mathrm{H})^{-}$; calculated $\mathrm{m} / \mathrm{z}$ 400.1303. M. pt. found: $253-255^{\circ} \mathrm{C}$. FT-IR (ATR): $\bar{v} / \mathrm{cm}^{-1}$ : 2800-3500, 3076, 2837, 1504, 1145. UV $\lambda_{\max }\left(0.1 \mathrm{mM}\right.$ in DMSO): $318 \mathrm{~nm}\left(\varepsilon=53,000 \mathrm{~cm}^{-1} \mathrm{M}^{-1}\right)$. TGA (Air): Weight loss at $300{ }^{\circ} \mathrm{C}(2.56 \%)$; Onset temperature $\left(333^{\circ} \mathrm{C}\right) .{ }^{1} \mathrm{H}$ NMR $\left(500 \mathrm{MHz}, \mathrm{DMSO}-d_{6}\right) \delta: 3.87(\mathrm{~s}, 6 \mathrm{H}), 6.36(\mathrm{~d}, J 2.2$ $\mathrm{Hz}, 1 \mathrm{H}), 6.49$ (dd, J 8.8, $2.2 \mathrm{~Hz}, 1 \mathrm{H}), 7.13(\mathrm{~d}, J 8.9 \mathrm{~Hz}, 4 \mathrm{H}), 8.42-8.45$ (d, J $8.8 \mathrm{~Hz}, 1 \mathrm{H}), 8.44(\mathrm{~d}, J 8.9 \mathrm{~Hz}, 4 \mathrm{H}) 10.42$ $(s, 1 H), 13.40(s, 1 H) .{ }^{13} \mathrm{C} N M R\left(125 \mathrm{MHz}, \mathrm{DMSO}-d_{6}\right) \delta: 56.0,103.5,109.1,109.6,114.9,127.5,130.9,131.8$, $163.9,164.2,164.5,169.2,170.7$. 
4-(4,6-Bis(4-fluorophenyl)-1,3,5-triazin-2-yl)benzene-1,3-diol (7). $\mathrm{AlCl}_{3}(0.13 \mathrm{~g}, 0.99 \mathrm{mmol})$ was added to a suspension of 2-chloro-4,6-bis(4-fluorophenyl)-1,3,5-triazine 3 (0.25 g, $0.82 \mathrm{mmol}$ ) and resorcinol (0.11 g, 0.99 $\mathrm{mmol})$ in 1,2-dichlorobenzene $(10 \mathrm{~mL})$ and the mixture was stirred at $130{ }^{\circ} \mathrm{C}$ for 3 hours under nitrogen. The reaction mixture was cooled to room temperature and $10 \% \mathrm{v} / \mathrm{v}$ aqueous $\mathrm{HCl}(30 \mathrm{~mL})$ was added and stirred for 30 mins. The pink coloured precipitate was collected by filtration, washed with water $(50 \mathrm{~mL})$ and dried at 70 ${ }^{\circ} \mathrm{C}$ in vacuo (60 mbar). No further purification was required and the pink coloured solid 7 ( $\left.0.26 \mathrm{~g}, 84 \%\right)$ was used in the subsequent step. HRMS: found $\mathrm{m} / \mathrm{z} 376.0909$ [M-H]; calculated $\mathrm{m} / \mathrm{z}$ 376.0903. M. pt. found: $333-335^{\circ} \mathrm{C}$. FT-IR (ATR): $\bar{v} / \mathrm{cm}^{-1}: 3250-3500,3072,1519,1504,1142$. UV $\lambda_{\max }\left(0.1 \mathrm{mM}\right.$ in DMSO): $342 \mathrm{~nm}\left(\varepsilon=21,000 \mathrm{~cm}^{-1}\right.$ $\left.\mathrm{M}^{-1}\right)$. TGA (Air): Weight loss at $300{ }^{\circ} \mathrm{C}(4.78 \%)$; Onset temperature $\left(325^{\circ} \mathrm{C}\right) .{ }^{1} \mathrm{H}$ NMR $\left(500 \mathrm{MHz}, \mathrm{DMSO}-d_{6}\right) \delta$ : $6.32(\mathrm{~d}, J 2.4 \mathrm{~Hz}, 1 \mathrm{H}), 6.46$ (dd, J 8.8, $2.4 \mathrm{~Hz}, 1 \mathrm{H}), 7.39(\mathrm{~m}, 4 \mathrm{H}), 8.37$ (d, J $8.8 \mathrm{~Hz}, 1 \mathrm{H}), 8.48-8.50(\mathrm{~m}, 4 \mathrm{H}), 10.45(\mathrm{~s}$, 1H), $12.99(\mathrm{~s}, 1 \mathrm{H}) .{ }^{13} \mathrm{C}$ NMR (125 MHz, DMSO-d $)$ \&: 103.5, 109.27, 109.32, 116.5 (d, J $\left.23 \mathrm{~Hz}\right), 129.1(\mathrm{~d}, J 3 \mathrm{~Hz})$, $131.6(\mathrm{~d}, J 10 \mathrm{~Hz}), 132.0,164.2,164.8,165.1$ (d, J $245 \mathrm{~Hz}), 168.9,171.0 .{ }^{19} \mathrm{~F} \mathrm{NMR}$ (400 MHz, DMSO) $\delta:-106.1$ (m).

2-(4,6-Diphenyl-1,3,5-triazin-2-yl)benzene-1,3,5-triol (8). Phloroglucinol (0.4664 g, $3.70 \mathrm{mmol}$ ) and 2-chloro4,6-diphenyl-1,3,5-triazine 1 (0.66 g, $2.47 \mathrm{mmol}$ ) were added to a 1:4 mixture of anhydrous DCM and anhydrous diethyl ether $(25 \mathrm{ml}) . \mathrm{AlCl}_{3}(0.4931 \mathrm{~g}, 3.70 \mathrm{mmol})$ catalyst was added and the mixture was refluxed for 16 hours under nitrogen. The solvent was removed under reduced pressure and the solid was suspended in $10 \% \mathrm{v} / \mathrm{v}$ aqueous $\mathrm{HCl}(25 \mathrm{~mL})$. The suspension was transferred to a centrifuge tube and spun at $3400 \mathrm{rpm}$ for 5 mins. The supernatant was removed, and the pellet was re-suspended and spun at $3400 \mathrm{rpm}$ for 5 mins. in distilled water $(25 \mathrm{~mL})$ and the supernatant removed. The crude product was collected by filtration and dried at $70{ }^{\circ} \mathrm{C}$ in vacuo (60 mbar). No further purification was required and the red coloured crude product 8 (0.79 $\mathrm{g}, 60 \%)$ was used in the subsequent step. HRMS: found $\mathrm{m} / \mathrm{z} 356.1046(\mathrm{M}-\mathrm{H})$; calculated $\mathrm{m} / \mathrm{z} 356.1041$. M. pt. found: 244-245 ${ }^{\circ} \mathrm{C}$. FT-IR (ATR): $\bar{v} / \mathrm{cm}^{-1}: 3150-3500,3026,1508,1479,1282$. UV $\lambda_{\max }(0.1 \mathrm{mM}$ in DMSO): $330 \mathrm{~nm}(\varepsilon=$ $\left.33,000 \mathrm{~cm}^{-1} \mathrm{M}^{-1}\right)$. TGA (Air): Weight loss at $300{ }^{\circ} \mathrm{C}(2.80 \%)$; Onset temperature $\left(372{ }^{\circ} \mathrm{C}\right) .{ }^{1} \mathrm{H} \mathrm{NMR}(400 \mathrm{MHz}$,

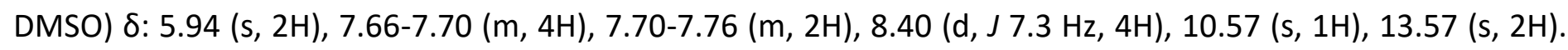

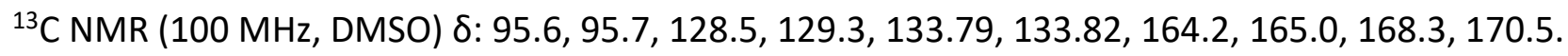

4-(4,6-Di([1,1'-biphenyl]-4-yl)-1,3,5-triazin-2-yl)benzene-1,3-diol (9). 2,4-Bis([1,1'-biphenyl]-4-yl)-6-chloro1,3,5-triazine 4 (2.00 g, $4.76 \mathrm{mmol})$, resorcinol $(0.63 \mathrm{~g}, 5.72 \mathrm{mmol})$ and $\mathrm{AlCl}_{3}(0.83 \mathrm{~g}, 6.19 \mathrm{mmol})$ were added to 1,2-dichlorobenzene $(100 \mathrm{~mL})$ and stirred at $130{ }^{\circ} \mathrm{C}$ for 16 hours under nitrogen. The mixture was cooled to room temperature, $10 \% \mathrm{v} / \mathrm{v}$ aqueous $\mathrm{HCl}(200 \mathrm{~mL})$ was added and the suspension was stirred at room temperature for 30 minutes. The precipitate was collected by filtration and washed with water $(100 \mathrm{~mL})$. The red coloured crude product $9(1.51 \mathrm{~g}, 64 \%)$ was dried at $70{ }^{\circ} \mathrm{C}$ in vacuo $(60 \mathrm{mbar})$; no further purification was required and 9 was used in the subsequent step. HRMS: found $m / z 494.1862(\mathrm{M}+\mathrm{H})^{+}$; calculated $\mathrm{m} / z$ 494.1863. M. pt. found: $264-266^{\circ} \mathrm{C}$. FT-IR (ATR): $\bar{v} / \mathrm{cm}^{-1}: 2900-3550,3057,3030,1506,1254$. UV $\lambda_{\max }(0.1 \mathrm{mM}$ in DMSO): $322 \mathrm{~nm}\left(\varepsilon=60,000 \mathrm{~cm}^{-1} \mathrm{M}^{-1}\right)$. TGA (Air): Weight loss at $300{ }^{\circ} \mathrm{C}(7.76 \%)$; Onset temperature $\left(336{ }^{\circ} \mathrm{C}\right) .{ }^{1} \mathrm{H} \mathrm{NMR}$ $\left(400 \mathrm{MHz}, \mathrm{DMSO}-d_{6}\right) \delta: 6.40(\mathrm{~d}, J 2.3 \mathrm{~Hz}, 1 \mathrm{H}), 6.55$ (dd, J 8.9, 2.3 Hz, 1H), $7.46(\mathrm{t}, J 7.3 \mathrm{~Hz}, 2 \mathrm{H}), 7.51-7.56(\mathrm{~m}, 4 \mathrm{H})$, $7.79(\mathrm{~m}, 4 \mathrm{H}), 7.93(\mathrm{~d}, J 8.5 \mathrm{~Hz}, 4 \mathrm{H}), 8.50(\mathrm{~d}, J 8.9 \mathrm{~Hz}, 1 \mathrm{H}), 8.60(\mathrm{~d}, J 8.5 \mathrm{~Hz}, 4 \mathrm{H}), 10.51(\mathrm{~s}, 1 \mathrm{H}), 13.29(\mathrm{~s}, 1 \mathrm{H}) .{ }^{13} \mathrm{C}$ NMR $\left(100 \mathrm{MHz}_{\mathrm{CDCl}}\right)$ $\delta:$ 103.0, 108.9, 109.0, 127.0, 127.2, 128.4, 129.08, 129.11, 131.5, 133.6, 138.9, 144.6, $163.8,164.3,169.1,170$.

Diethyl 2-(4-(4,6-diphenyl-1,3,5-triazin-2-yl)-3-hydroxyphenoxy)-2-methylmalonate (10). A mixture of 4-(4,6diphenyl-1,3,5-triazin-2-yl)benzene-1,3-diol $5(0.25 \mathrm{~g}, 0.73 \mathrm{mmol})$ and $\mathrm{Na}_{2} \mathrm{CO}_{3}(0.15 \mathrm{~g}, 1.46 \mathrm{mmol})$ in DMF (20 $\mathrm{mL}$ ) was heated to $70^{\circ} \mathrm{C}$. A solution of diethyl 2-bromo-2-methylmalonate $(0.20 \mathrm{~g}, 0.81 \mathrm{mmol})$ in DMF (10 mL) was added slowly, and once the addition was complete the mixture was heated at $110^{\circ} \mathrm{C}$ overnight. The mixture was filtered whilst hot, the solvent was removed from the filtrate under reduced pressure and the residue was 
redissolved in ethyl acetate/ $\mathrm{MeOH}(8 / 2, \mathrm{v} / \mathrm{v}, 50 \mathrm{~mL})$. The organic layer was washed with $5 \% \mathrm{v} / \mathrm{v}$ aqueous acetic acid $(25 \mathrm{~mL}), 0.25 \mathrm{M}$ aqueous $\mathrm{NaHCO}_{3}(25 \mathrm{~mL})$ and brine $(25 \mathrm{~mL})$. The solvent was dried using sodium sulfate and removed under reduced pressure. The crude product was suspended in $\mathrm{MeOH}(40 \mathrm{~mL})$, filtered and the off-white coloured powder was dried at $70{ }^{\circ} \mathrm{C}$ in vacuo $(60 \mathrm{mbar})$ to yield 10 (0.23 g, 60.5\%). HRMS: found $\mathrm{m} / \mathrm{z}$ 514.1976 $(\mathrm{M}+\mathrm{H})^{+}$; calculated $\mathrm{m} / z$ 514.1973. M. pt. found: $122-124{ }^{\circ} \mathrm{C}$. FT-IR (ATR): $\bar{v} / \mathrm{cm}^{-1}: 3031,2981,1755$, 1735, 1525, 1508, 1271, 1139. UV $\lambda_{\max }\left(0.1 \mathrm{mM}\right.$ in $\left.\mathrm{CHCl}_{3}\right): 340 \mathrm{~nm}\left(\varepsilon=19,000 \mathrm{~cm}^{-1} \mathrm{M}^{-1}\right)$. TGA (Air): Weight loss at $300{ }^{\circ} \mathrm{C}(0.81 \%)$; Onset temperature $\left(342{ }^{\circ} \mathrm{C}\right) .{ }^{1} \mathrm{H} \mathrm{NMR}(500 \mathrm{MHz}, \mathrm{CDCl}) \delta: 1.31(\mathrm{t}, J 7.1 \mathrm{~Hz}, 6 \mathrm{H}), 1.92(\mathrm{~s}, 3 \mathrm{H})$, $4.33(\mathrm{q}, J 7.1 \mathrm{~Hz}, 4 \mathrm{H}), 6.61(\mathrm{~d}, J 2.5 \mathrm{~Hz}, 1 \mathrm{H}), 6.66(\mathrm{dd}, J$ 8.9, $2.5 \mathrm{~Hz}, 1 \mathrm{H}), 7.57-7.60(\mathrm{~m}, 4 \mathrm{H}), 7.65(\mathrm{~m}, 2 \mathrm{H}), 8.63-8.65$ $(\mathrm{m}, 5 \mathrm{H}), 13.45(\mathrm{~s}, 1 \mathrm{H}) .{ }^{13} \mathrm{C} \mathrm{NMR}\left(100 \mathrm{MHz} \mathrm{CDCl}_{3}\right) \delta: 14.0,20.8,62.5,82.6,106.5,110.6,112.5,128.9,129.0$, $131.2,133.1,135.3,160.7,163.7,168.3,170.6,171.2$.

Diethyl 2-(4-(4,6-di([1,1'-biphenyl]-4-yl)-1,3,5-triazin-2-yl)-3-hydroxyphenoxy)-2-methylmalonate (11). A solution of 4-(4,6-di([1,1'-biphenyl]-4-yl)-1,3,5-triazin-2-yl)benzene-1,3-diol 9 (0.50 g, $1.01 \mathrm{mmol})$ and $\mathrm{Na}_{2} \mathrm{CO}_{3}$ $(0.22 \mathrm{~g}, 2.02 \mathrm{mmol})$ in DMF $(50 \mathrm{~mL})$ was stirred at $70{ }^{\circ} \mathrm{C}$ for 1 hour. A solution of diethyl 2-bromo-2methylmalonate $(0.31 \mathrm{~g}, 1.22 \mathrm{mmol})$ in DMF $(50 \mathrm{~mL})$ was added dropwise, and once the addition was complete the mixture was stirred at $110^{\circ} \mathrm{C}$ for 16 hours. The mixture was filtered whilst hot and the solvent was removed under reduced pressure. The residue was redissolved in toluene/acetone $(7 / 3, v / v, 100 \mathrm{~mL})$ and filtered to remove inorganic salts. The solvent was removed under reduced pressure and the residue was suspended in $\mathrm{MeOH}(20 \mathrm{~mL})$ and filtered. The crude product was purified by flash column chromatography on silica gel $(100 \%$ $\mathrm{CHCl}_{3}$ (Rf value for 11 in $\mathrm{CHCl}_{3}=0.42$ ). The solvent was removed under reduced pressure and the red coloured solid was dried at $70{ }^{\circ} \mathrm{C}$ in vacuo (60 mbar) to yield $11(0.40 \mathrm{~g}, 59 \%)$. HRMS: found $\mathrm{m} / \mathrm{z} 666.2600(\mathrm{M}+\mathrm{H})^{+}$; calculated $\mathrm{m} / \mathrm{z} 666.2599$. M. pt. found: $150-151^{\circ} \mathrm{C}$. FT-IR (ATR): $\bar{v} / \mathrm{cm}^{-1}: 3091,2947,2896,1722,1708,1508$, 1245, 1157. UV $\lambda_{\max }\left(0.1 \mathrm{mM}\right.$ in $\left.\mathrm{CHCl}_{3}\right): 323 \mathrm{~nm}\left(\varepsilon=75,000 \mathrm{~cm}^{-1} \mathrm{M}^{-1}\right)$. TGA (Air): Weight loss at $300{ }^{\circ} \mathrm{C}(1.29 \%)$; Onset temperature $\left(326^{\circ} \mathrm{C}\right) .{ }^{1} \mathrm{H}$ NMR $\left(500 \mathrm{MHz} \mathrm{CDCl}_{3}\right) \delta: 1.31(\mathrm{t}, J 7.1 \mathrm{~Hz}, 6 \mathrm{H}), 1.93(\mathrm{~s}, 3 \mathrm{H}), 4.35(\mathrm{q}, J 7.1 \mathrm{~Hz}$, $4 \mathrm{H}), 6.63(\mathrm{~d}, J 2.5 \mathrm{~Hz}, 1 \mathrm{H}), 6.68(\mathrm{dd}, J 8.9,2.5 \mathrm{~Hz}, 1 \mathrm{H}), 7.43(\mathrm{~m}, 2 \mathrm{H}), 7.50-7.53(\mathrm{~m}, 4 \mathrm{H}), 7.71(\mathrm{~m}, 4 \mathrm{H}), 7.81(\mathrm{~m}, 4 \mathrm{H})$, $8.65(\mathrm{~d}, J 8.9 \mathrm{~Hz}, 1 \mathrm{H}), 8.65-8.70(\mathrm{~m}, 4 \mathrm{H}), 13.53(\mathrm{~s}, 1 \mathrm{H}) .{ }^{13} \mathrm{C} \mathrm{NMR}\left(100 \mathrm{MHz}, \mathrm{CDCl}_{3}\right) \delta: 13.5,20.33,62.0,82.2$, 106.0, 110.1, 112.1, 126.8, 127.0, 127.7, 128.5, 129.0, 130.7, 133.7, 139.6, 145.3, 160.2, 163.2, 167.8, 170.7

3-[4-(4,6-Diphenyl-1,3,5-triazin-2-yl)-3-hydroxyphenoxy]-1,2-propanediol (12). A mixture of 4-(4,6-diphenyl1,3,5-triazin-2-yl)benzene-1,3-diol 5 (1.50 g, $4.39 \mathrm{mmol}$ ), $\mathrm{Na}_{2} \mathrm{CO}_{3}(1.40 \mathrm{~g}, 13.18 \mathrm{mmol}$ ) and $\mathrm{KI}(1.10 \mathrm{~g}, 6.59 \mathrm{mmol})$ in DMF (100 mL) was stirred at $70{ }^{\circ} \mathrm{C}$. To this, a solution of 3-chloropropane-1,2-diol (1.95 g, $\left.17.58 \mathrm{mmol}\right)$ in DMF $\left(50 \mathrm{~mL}\right.$ ) was added and stirred at $110^{\circ} \mathrm{C}$ for 3 days. The mixture was filtered whilst hot and the solvent removed under reduced pressure. The residue was suspended in water $(75 \mathrm{~mL})$ and stirred at room temperature for 30 mins. The solid was collected by filtration and washed with water $(50 \mathrm{~mL})$. The crude solid was purified by flash column chromatography on silica gel (10\% MeOH in $\mathrm{CHCl}_{3}$, Rf value for 12 in $10 \% \mathrm{MeOH}$ in $\left.\mathrm{CHCl}_{3}=0.35\right)$. The solvent was removed under reduced pressure and the yellow coloured solid was dried at $70{ }^{\circ} \mathrm{C}$ in vacuo (60 mbar) to yield $12(1.35 \mathrm{~g}, 75 \%)$. HRMS: found $\mathrm{m} / \mathrm{z} 416.1611(\mathrm{M}+\mathrm{H})^{+}$; calculated $\mathrm{m} / \mathrm{z} 416.1605$. M. pt. found: 203-205 ${ }^{\circ} \mathrm{C}$. FT-IR (ATR): $\bar{v} / \mathrm{cm}^{-1}: 3100-3400,3060,2954,2921,2896,1511,1355,1262$. UV $\lambda_{\max }(0.1 \mathrm{mM}$ in DMSO): $342 \mathrm{~nm}\left(\varepsilon=24,000 \mathrm{~cm}^{-1} \mathrm{M}^{-1}\right)$. TGA (Air): Weight loss at $300{ }^{\circ} \mathrm{C}(2.26 \%)$; Onset temperature $\left(312^{\circ} \mathrm{C}\right) .{ }^{1} \mathrm{H}$ NMR $\left(400 \mathrm{MHz}\right.$, DMSO- $\left.d_{6}\right) \delta: 3.48(\mathrm{~m}, 2 \mathrm{H}), 3.80-3.87(\mathrm{~m}, 1 \mathrm{H}), 3.93-3.97(\mathrm{~m}, 1 \mathrm{H}), 4.07-4.11(\mathrm{~m}, 1 \mathrm{H}), 4.72(\mathrm{t}, J 5.7$ $\mathrm{Hz}, 1 \mathrm{H}), 5.02(\mathrm{~d}, J 5.2 \mathrm{~Hz}, 1 \mathrm{H}), 6.50(\mathrm{~d}, J 2.5 \mathrm{~Hz}, 1 \mathrm{H}), 6.62(\mathrm{dd}, J$ 9.0, $2.5 \mathrm{~Hz}, 1 \mathrm{H}), 7.63-7.66(\mathrm{~m}, 4 \mathrm{H}), 7.72(\mathrm{~m}, 2 \mathrm{H})$, 8.52-8.56 (m, 5H), $13.31(\mathrm{~s}, 1 \mathrm{H}) .{ }^{13} \mathrm{C} N M R\left(100 \mathrm{MHz}, \mathrm{DMSO}-d_{6}\right) \delta: 62.5,69.8,70.0,101.7,108.3,109.9,128.5$, $129.1,131.1,133.3,134.6,163.7,164.8,169.6,170.5$.

3-(4-(4,6-Bis(4-methoxyphenyl)-1,3,5-triazin-2-yl)-3-hydroxyphenoxy)propane-1,2-diol (13). A mixture of 4(4,6-bis(4-methoxyphenyl)-1,3,5-triazin-2-yl)benzene-1,3-diol 6 (0.25 g, $0.62 \mathrm{mmol}$ ), $\mathrm{Na}_{2} \mathrm{CO}_{3}$ (0.23 g, $\left.2.18 \mathrm{mmol}\right)$ and $\mathrm{KI}(0.16 \mathrm{~g}, 0.90 \mathrm{mmol})$ in DMF $(20 \mathrm{~mL})$ was stirred at $70{ }^{\circ} \mathrm{C}$. To this, a solution of 3-chloropropane-1,2-diol 
$(0.31 \mathrm{~g}, 2.80 \mathrm{mmol})$ in DMF $(5 \mathrm{~mL})$ was added and stirred at $110{ }^{\circ} \mathrm{C}$ for 7 days. The mixture was filtered whilst hot and more than $50 \%$ of the solvent removed under reduced pressure. $5 \% \mathrm{v} / \mathrm{v}$ Aqueous $\mathrm{HCl}(50 \mathrm{~mL}) \mathrm{was}$ added to the residue and the precipitate collected by filtration, washing with deionized water $(50 \mathrm{~mL})$. The crude solid was purified by flash column chromatography on silica gel $\left(10 \% \mathrm{MeOH}\right.$ in $\mathrm{CHCl}_{3}$, $\mathrm{Rf}$ value for 13 in $10 \% \mathrm{MeOH}$ in $\left.\mathrm{CHCl}_{3}=0.33\right)$. The solvent was removed under reduced pressure and the red coloured solid was dried at $70{ }^{\circ} \mathrm{C}$ in vacuo (60 mbar) to yield 13 (0.19 g, 64\%). HRMS: found $\mathrm{m} / z 476.1821(\mathrm{M}+\mathrm{H})^{+}$; calculated $\mathrm{m} / z$ 476.1816. M. pt. found: $182-185^{\circ} \mathrm{C}$. FT-IR (ATR): $\bar{v} / \mathrm{cm}^{-1}$ : 3050-3400, 3030, 2954, 2928, 2837, 1504, 1256, 1174. UV $\lambda_{\max }(0.1$ $\mathrm{mM}$ in DMSO): $321 \mathrm{~nm}\left(\varepsilon=55,000 \mathrm{~cm}^{-1} \mathrm{M}^{-1}\right)$. TGA (Air): Weight loss at $300{ }^{\circ} \mathrm{C}(5.66 \%)$; Onset temperature (310 $\left.{ }^{\circ} \mathrm{C}\right) .{ }^{1} \mathrm{H}$ NMR $\left(400 \mathrm{MHz}\right.$, DMSO- $\left.d_{6}\right)$ 8: 3.47-3.51 (m, 2H), 3.84-3.86 (m, $\left.1 \mathrm{H}\right), 3.88(\mathrm{~s}, 6 \mathrm{H}), 3.93-3.97(\mathrm{~m}, 1 \mathrm{H}), 4.07-$ $4.11(\mathrm{~m}, 1 \mathrm{H}), 4.71(\mathrm{t}, J 5.3 \mathrm{~Hz}, 1 \mathrm{H}), 5.01(\mathrm{~d}, J 4.9 \mathrm{~Hz}, 1 \mathrm{H}), 6.49$ (d, J $2.4 \mathrm{~Hz}, 1 \mathrm{H}), 6.62$ (dd, J 8.9, $2.4 \mathrm{~Hz}, 1 \mathrm{H}), 7.12$ (d, J 7.1 Hz, 4H), 8.41-8.47 (m, 5H), $13.41(\mathrm{~s}, 1 \mathrm{H}) .{ }^{13} \mathrm{C}$ NMR (100 MHz, DMSO-d6) $\delta: ~ 56.0,63.1,70.3,70.5,102.2$, $108.5,110.6,114.9,127.4,131.0,131.5,163.9,164.1,165.0,169.3,170.6$.

3-(4-(4,6-Bis(4-fluorophenyl)-1,3,5-triazin-2-yl)-3-hydroxyphenoxy)propane-1,2-diol (14). A mixture of 4-(4,6bis(4-fluorophenyl)-1,3,5-triazin-2-yl)benzene-1,3-diol 7 (1.00 g, $2.65 \mathrm{mmol}), \mathrm{KI}\left(0.68 \mathrm{~g}, 4.10 \mathrm{mmol}\right.$ ) and $\mathrm{Na}_{2} \mathrm{CO}_{3}$ $(0.84 \mathrm{~g}, 7.93 \mathrm{mmol})$ in DMF $(75 \mathrm{~mL})$ was stirred at $70^{\circ} \mathrm{C}$. To this, a solution of 3-chloropropane-1,2-diol (1.16 g, $10.49 \mathrm{mmol})$ in DMF $(25 \mathrm{~mL})$ was added and stirred at $110{ }^{\circ} \mathrm{C}$ for 16 hours. The mixture was filtered whilst hot and the solvent removed under reduced pressure. DMF $(5 \mathrm{~mL})$ was added to the residue followed by $5 \% \mathrm{v} / \mathrm{v}$ aqueous $\mathrm{HCl}(50 \mathrm{~mL})$. The precipitate was collected by filtration and washed with water $(40 \mathrm{~mL})$. The crude solid was purified by flash column chromatography on silica gel $\left(10 \% \mathrm{MeOH}\right.$ in $\mathrm{CHCl}_{3}$, $\mathrm{Rf}$ value for 14 in $10 \%$ $\mathrm{MeOH}$ in $\left.\mathrm{CHCl}_{3}=0.37\right)$. The solvent was removed under reduced pressure and the yellow coloured solid was dried at $70{ }^{\circ} \mathrm{C}$ in vacuo (60 mbar) to yield 14 (0.84 g, 70\%). HRMS: found $\mathrm{m} / \mathrm{z} 450.1278(\mathrm{M}-\mathrm{H})^{-}$; calculated $\mathrm{m} / \mathrm{z}$ 450.1271. M. pt. found: $182-185^{\circ} \mathrm{C}$. FT-IR (ATR): $\bar{v} / \mathrm{cm}^{-1}: 3100-3400,2932,1530,1504,1264,1236,1227$. UV $\lambda_{\max }\left(0.1 \mathrm{mM}\right.$ in DMSO): $342 \mathrm{~nm}\left(\varepsilon=21,000 \mathrm{~cm}^{-1} \mathrm{M}^{-1}\right)$. TGA (Air): Weight loss at $300{ }^{\circ} \mathrm{C}(4.07 \%)$; Onset temperature $\left(319^{\circ} \mathrm{C}\right) .{ }^{1} \mathrm{H}$ NMR $\left(400 \mathrm{MHz}\right.$, DMSO- $\left.d_{6}\right) \delta: 3.48(\mathrm{~m}, 2 \mathrm{H}), 3.82-3.87(\mathrm{~m}, 1 \mathrm{H}), 3.91-3.95(\mathrm{~m}, 1 \mathrm{H}), 4.05-$ $4.08(\mathrm{~m}, 1 \mathrm{H}), 4.74(\mathrm{t}, J 5.6 \mathrm{~Hz}, 1 \mathrm{H}), 5.04(\mathrm{~d}, J 5.1 \mathrm{~Hz}, 1 \mathrm{H}), 6.41(\mathrm{~d}, J 2.4 \mathrm{~Hz}, 1 \mathrm{H}), 6.56(\mathrm{dd}, J 9.0,2.4 \mathrm{~Hz}, 1 \mathrm{H}), 7.35-$ $7.39(\mathrm{~m}, 4 \mathrm{H}), 8.35(\mathrm{~d}, J 9.0 \mathrm{~Hz}, 1 \mathrm{H}), 8.34-8.45(\mathrm{~m}, 4 \mathrm{H}), 12.99(\mathrm{~s}, 1 \mathrm{H}) .{ }^{13} \mathrm{C} \mathrm{NMR}\left(100 \mathrm{MHz}, \mathrm{DMSO}-d_{6}\right) \delta: 62.6,69.8$, 70.0, 101.6, 108.1, 109.7, 116.0 (d, J 22 Hz), 130.8 (d, J 3 Hz), 131.1 (d, J 9 Hz), 132.4, 163.6, 164.8, 165.0 (d, J $254 \mathrm{~Hz}), 168.3,170.3 .{ }^{19} \mathrm{~F} \mathrm{NMR}(400 \mathrm{MHz}, \mathrm{DMSO}) \delta:-106.2(\mathrm{~m}, 2 \mathrm{~F})$.

3-[4-(4,6-Diphenyl-1,3,5-triazin-2-yl)-3,5-dihydroxyphenoxy]-1,2-propanediol (15). A mixture of 4-(4,6diphenyl-1,3,5-triazin-2-yl)benzene-1,3-diol 8 (1.50 g, $4.20 \mathrm{mmol}), \mathrm{Na}_{2} \mathrm{CO}_{3}(1.55 \mathrm{~g}, 14.70 \mathrm{mmol})$ and $\mathrm{KI}(1.22 \mathrm{~g}$, $7.36 \mathrm{mmol})$ in DMF $(100 \mathrm{~mL})$ was stirred at $70{ }^{\circ} \mathrm{C}$. To this, a solution of 3-chloropropane-1,2-diol (2.09 g, 18.9 $\mathrm{mmol})$ in DMF $(50 \mathrm{~mL})$ was added and stirred at $110^{\circ} \mathrm{C}$ for 5 days. The mixture was filtered whilst hot and the solvent removed under reduced pressure. The residue was suspended in $10 \% \mathrm{v} / \mathrm{v}$ aqueous $\mathrm{HCl}(50 \mathrm{~mL})$ and stirred at room temperature for 30 mins. The solid was collected by filtration and washed with water $(50 \mathrm{~mL})$. The crude solid was dissolved in hot DMF $(10 \mathrm{~mL})$ and cooled to room temperature. To this, $\mathrm{MeOH}(70 \mathrm{~mL})$ was added to form a precipitate which was collected by filtration and washed with $\mathrm{MeOH}(30 \mathrm{~mL})$. The red coloured solid was dried at $70{ }^{\circ} \mathrm{C}$ in vacuo (60 mbar) to yield 15 (1.23 g, 68\%). HRMS: found $\mathrm{m} / \mathrm{z} 432.1560(\mathrm{M}+\mathrm{H})^{+}$; calculated $\mathrm{m} / \mathrm{z}$ 432.1554. M. pt. found: $236-238^{\circ} \mathrm{C}$. FT-IR (ATR): $\bar{v} / \mathrm{cm}^{-1}:$ 3100-3500, 3058, 2900, $1511,1152$. UV $\lambda_{\max }\left(0.1 \mathrm{mM}\right.$ in DMSO): $327 \mathrm{~nm}\left(\varepsilon=34,000 \mathrm{~cm}^{-1} \mathrm{M}^{-1}\right)$. TGA (Air): Weight loss at $300{ }^{\circ} \mathrm{C}(3.61 \%) ;$ Onset temperature $\left(329^{\circ} \mathrm{C}\right) .{ }^{1} \mathrm{H}$ NMR $\left(400 \mathrm{MHz}, \mathrm{DMSO}-d_{6}\right) \delta: 3.46(\mathrm{~d}, J 5.5 \mathrm{~Hz}, 2 \mathrm{H}), 3.78-3.81(\mathrm{~m}, 1 \mathrm{H}), 3.86-3.90(\mathrm{~m}$, $1 \mathrm{H}), 4.01-4.04(\mathrm{~m}, 1 \mathrm{H}), 4.71(\mathrm{~s}, 1 \mathrm{H}), 4.99(\mathrm{~s}, 1 \mathrm{H}), 6.00(\mathrm{~s}, 2 \mathrm{H}), 7.63-7.67(\mathrm{~m}, 4 \mathrm{H}), 7.74(\mathrm{~m}, 2 \mathrm{H}), 8.36(\mathrm{~m}, 4 \mathrm{H}), 13.53$ $(s, 2 H) .{ }^{13} \mathrm{C}$ NMR $\left(100 \mathrm{MHz}, \mathrm{DMSO}-d_{6}\right) \delta: 62.6,69.7,70.0,94.5,96.6,128.5,129.3,133.7,133.8,164.0,165.3$, $168.4,170.5$. 
3-\{4-[4,6-Bis(4-biphenylyl)-1,3,5-triazin-2-yl]-3,5-dihydroxyphenoxy\}-1,2-propanediol (16). A mixture of 4(4,6-di([1,1'-biphenyl]-4-yl)-1,3,5-triazin-2-yl)benzene-1,3-diol 9 (0.25 g, 0.51 mmol), $\mathrm{Na}_{2} \mathrm{CO}_{3}$ (0.16 g, 1.52 $\mathrm{mmol})$ and $\mathrm{KI}(0.13 \mathrm{~g}, 0.77 \mathrm{mmol})$ in DMF $(10 \mathrm{~mL})$ was stirred at $70{ }^{\circ} \mathrm{C}$. To this, a solution of 3-chloropropane1,2-diol (0.23 g, $2.04 \mathrm{mmol})$ in DMF $(5 \mathrm{~mL})$ was added and stirred at $110{ }^{\circ} \mathrm{C}$ for 3 days. The mixture was filtered whilst hot and the solvent was removed under reduced pressure. The residue was suspended in $10 \% \mathrm{v} / \mathrm{v}$ aqueous $\mathrm{HCl}(15 \mathrm{~mL})$ and stirred at room temperature for 30 mins. The solid was collected by filtration and washed with water $(30 \mathrm{~mL})$. The crude solid was purified by flash column chromatography on silica gel $(10 \%$ $\mathrm{MeOH}$ in $\mathrm{CHCl}_{3}$, $\mathrm{Rf}$ value for 16 in $10 \% \mathrm{MeOH}$ in $\left.\mathrm{CHCl}_{3}=0.40\right)$. The solvent was removed under reduced pressure and the red coloured solid was dried at $70{ }^{\circ} \mathrm{C}$ in vacuo (60 mbar) to yield 16 (0.17 g, 59\%). HRMS: found $\mathrm{m} / \mathrm{z}$ 568.2242 $(\mathrm{M}+\mathrm{H})^{+}$; calculated $\mathrm{m} / \mathrm{z} 568.2231$. M. pt. found: $251-252{ }^{\circ} \mathrm{C}$. FT-IR (ATR): $\bar{v} / \mathrm{cm}^{-1}: 3000-3600,3030$, 2926, 1506, 1260. UV $\lambda_{\max }\left(0.1 \mathrm{mM}\right.$ in DMSO): $323 \mathrm{~nm}\left(\varepsilon=74,000 \mathrm{~cm}^{-1} \mathrm{M}^{-1}\right)$. TGA (Air): Weight loss at $300^{\circ} \mathrm{C}$ (3.29\%); Onset temperature $\left(346{ }^{\circ} \mathrm{C}\right) .{ }^{1} \mathrm{H}$ NMR $\left(500 \mathrm{MHz}, \mathrm{DMSO}-d_{6}\right) \delta: 3.47-3.49(\mathrm{~m}, 2 \mathrm{H}), 3.81-3.86(\mathrm{~m}, 1 \mathrm{H})$, 3.92-3.95 (m, 1H), 4.05-4.08 (m, 1H), $4.73(\mathrm{t}, J 5.6 \mathrm{~Hz}), 5.02(\mathrm{~d}, J 5.2 \mathrm{~Hz}, 1 \mathrm{H}), 6.47(\mathrm{~d}, J 2.4 \mathrm{~Hz}, 1 \mathrm{H}), 6.61$ (dd, J 8.9, $2.4 \mathrm{~Hz}, 1 \mathrm{H}), 7.43(\mathrm{~m}, 2 \mathrm{H}), 7.48-7.51(\mathrm{~m}, 4 \mathrm{H}), 7.71(\mathrm{~m}, 4 \mathrm{H}), 7.84(\mathrm{~d}, J 8.5 \mathrm{~Hz}, 4 \mathrm{H}), 8.44(\mathrm{~d}, J 8.9 \mathrm{~Hz}, 1 \mathrm{H}), 8.59(\mathrm{~d}, J$ $8.5 \mathrm{~Hz}, 4 \mathrm{H}), 13.24(\mathrm{~s}, 1 \mathrm{H}) .{ }^{13} \mathrm{C}$ NMR $\left(100 \mathrm{MHz}, \mathrm{DMSO}-d_{6}\right) \delta: 63.1,70.3,70.4,102.1,108.6,110.4,127.4,127.6$, $128.8,129.5,130.0,131.5,133.9,139.4,145.1,164.1,165.2,169.6,170.9$.

2-(4,6-Bis(4-methoxyphenyl)-1,3,5-triazin-2-yl)-5-(2-hydroxyethoxy)phenol (17). A solution of 4-(4,6-bis(4methoxyphenyl)-1,3,5-triazin-2-yl)benzene-1,3-diol $6(0.25 \mathrm{~g}, 0.62 \mathrm{mmol})$ and $\mathrm{Na}_{2} \mathrm{CO}_{3}(0.13 \mathrm{~g}, 1.25 \mathrm{mmol})$ in DMF $(20 \mathrm{~mL})$ was stirred at $70{ }^{\circ} \mathrm{C}$. To this, a solution of 2-bromoethanol $(0.16 \mathrm{~g}, 1.25 \mathrm{mmol})$ in DMF $(5 \mathrm{~mL})$ was added and the mixture was stirred at $110{ }^{\circ} \mathrm{C}$ for 16 hours. The reaction mixture was filtered whilst hot and the solvent was removed under reduced pressure. The residue was suspended in water $(30 \mathrm{~mL})$, stirred for 1 hour at room temperature and filtered. The brown coloured solid was resuspended in acetone ( $5 \mathrm{~mL})$, collected by filtration and washed with acetone $(10 \mathrm{~mL})$. The beige coloured solid was dried overnight at $70{ }^{\circ} \mathrm{C}$ in vacuo $(60$ mbar) to yield $17(0.17 \mathrm{~g}, 61 \%)$. HRMS: found $\mathrm{m} / \mathrm{z} 446.1716(\mathrm{M}+\mathrm{H})^{+}$; calculated $\mathrm{m} / \mathrm{z} 446.1721$. M. pt. found: 121-123 ${ }^{\circ} \mathrm{C}$. FT-IR (ATR): $\bar{v} / \mathrm{cm}^{-1}: 3100-3400,3005,2931,2835,1500,1251,1170$. UV $\lambda_{\max }(0.1 \mathrm{mM}$ in DMSO): $322 \mathrm{~nm}\left(\varepsilon=61,000 \mathrm{~cm}^{-1} \mathrm{M}^{-1}\right)$. TGA (Air): Weight loss at $300{ }^{\circ} \mathrm{C}(1.71 \%)$; Onset temperature $\left(339{ }^{\circ} \mathrm{C}\right)$. ${ }^{1} \mathrm{H} N M R$

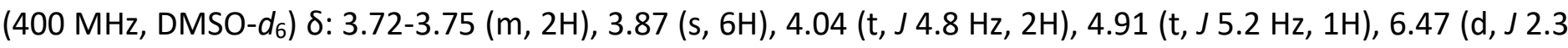
$\mathrm{Hz}, 1 \mathrm{H}), 6.59(\mathrm{dd}, J$ 9.0, $2.3 \mathrm{~Hz}, 1 \mathrm{H}), 7.10(\mathrm{~d}, J 8.9 \mathrm{~Hz}, 4 \mathrm{H}), 8.39-8.44(\mathrm{~m}, 5 \mathrm{H}), 13.4(\mathrm{~s}, 1 \mathrm{H}) .{ }^{13} \mathrm{C} \mathrm{NMR}(100 \mathrm{MHz}$, DMSO- $\left.d_{6}\right) \delta: 55.5,59.4,69.9,101.5,107.9,110.0,114.3,126.9,130.4,130.9,163.3,163.6,164.4,168.6,170.0$. 2-(4,6-Bis(4-fluorophenyl)-1,3,5-triazin-2-yl)-5-(2-hydroxyethoxy)phenol (18). A mixture of 4-(4,6-bis(4fluorophenyl)-1,3,5-triazin-2-yl)benzene-1,3-diol 7 (0.25 g, $0.66 \mathrm{mmol}$ ) and $\mathrm{Na}_{2} \mathrm{CO}_{3}(0.14 \mathrm{~g}, 1.32 \mathrm{mmol})$ in DMF $(20 \mathrm{~mL})$ was stirred at $70^{\circ} \mathrm{C}$. To this, a solution of 2-bromoethanol $(0.17 \mathrm{~g}, 1.32 \mathrm{mmol})$ in DMF $(5 \mathrm{~mL})$ was added and stirred at $110{ }^{\circ} \mathrm{C}$ for 16 hours. The mixture was filtered whilst hot and the solvent was removed under reduced pressure. DMF $(5 \mathrm{~mL})$ was added to the residue followed by $5 \% \mathrm{v} / \mathrm{v}$ aqueous $\mathrm{HCl}(50 \mathrm{~mL})$, and the precipitate was collected by filtration, washing with water $(40 \mathrm{~mL})$. The crude solid was purified by flash column chromatography on silica gel $\left(10 \% \mathrm{MeOH}\right.$ in $\mathrm{CHCl}_{3}$, $\mathrm{Rf}$ value for 18 in $10 \% \mathrm{MeOH}$ in $\left.\mathrm{CHCl}_{3}=0.38\right)$ and the solvent was removed under reduced pressure. The yellow coloured solid was dried at $70{ }^{\circ} \mathrm{C}$ in vacuo (60 mbar) to yield 18 (0.23 g, 83\%). HRMS: found $m / z 420.1175(\mathrm{M}-\mathrm{H})^{-}$; calculated $\mathrm{m} / \mathrm{z} 420.1165$. M. pt. found: $220-222{ }^{\circ} \mathrm{C}$. FT-IR (ATR): $\bar{v} / \mathrm{cm}^{-1}: 3150-3450,3081,2934,1506,1260$. UV $\lambda_{\max }\left(0.1 \mathrm{mM}\right.$ in DMSO): $345 \mathrm{~nm}\left(\varepsilon=19,000 \mathrm{~cm}^{-1} \mathrm{M}^{-1}\right)$. TGA (Air): Weight loss at $300{ }^{\circ} \mathrm{C}(8.59 \%)$; Onset temperature $\left(309^{\circ} \mathrm{C}\right) .{ }^{1} \mathrm{H}$ NMR $\left(400 \mathrm{MHz}, \mathrm{DMSO}-d_{6}\right) \delta$ : 3.74-3.76 $(\mathrm{m}, 2 \mathrm{H}), 4.04(\mathrm{t}, J 4.8 \mathrm{~Hz}, 2 \mathrm{H}), 4.92(\mathrm{~s}, 1 \mathrm{H}), 6.45(\mathrm{~d}, J 2.5 \mathrm{~Hz}, 1 \mathrm{H}), 6.57(\mathrm{dd}, J$ 9.0, $2.5 \mathrm{~Hz}, 1 \mathrm{H}), 7.37-7.42(\mathrm{~m}, 4 \mathrm{H})$,

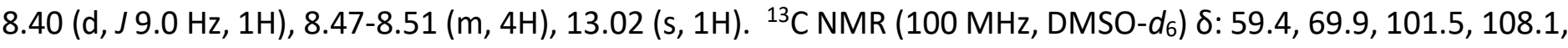
109.7, 116.0 (d, J 22Hz, 130.8, 131.1 (d, J $9 \mathrm{~Hz}), 132.4,163.6,164.7,165.0$ (d, J $254 \mathrm{~Hz}), 168.3,170.3 .{ }^{19} \mathrm{~F} \mathrm{NMR}$ (400 MHz, DMSO) $\delta:-106.3(\mathrm{~m}, 2 \mathrm{~F})$. 
2-(4,6-Diphenyl-1,3,5-triazin-2-yl)-5-(2-hydroxyethoxy)benzene-1,3-diol (19). A solution of 2-(4,6-diphenyl1,3,5-triazin-2-yl)benzene-1,3,5-triol 8 (3.00 g, $8.40 \mathrm{mmol}$ ) and $\mathrm{Na}_{2} \mathrm{CO}_{3}(1.78 \mathrm{~g}, 16.80 \mathrm{mmol})$ in DMF (100 mL) was stirred at $70{ }^{\circ} \mathrm{C}$. To this, a solution of 2-bromoethanol $(2.10 \mathrm{~g}, 16.80 \mathrm{mmol})$ in DMF $(50 \mathrm{~mL})$ was added and the mixture was stirred at $110{ }^{\circ} \mathrm{C}$ for 16 hours. The mixture was filtered whilst hot and the solvent was removed under reduced pressure. The residue was suspended in water $(100 \mathrm{~mL})$, ultrasonicated for 10 mins and stirred at room temperature for 30 mins. The solid was collected by filtration and washed with water $(100 \mathrm{~mL})$. The light yellow coloured solid was dried overnight at $70{ }^{\circ} \mathrm{C}$ in vacuo (60 mbar) to yield 19 (3.20 g, 95\%). HRMS: found $\mathrm{m} / \mathrm{z} 402.1452(\mathrm{M}+\mathrm{H})^{+}$; calculated $\mathrm{m} / \mathrm{z}$ 402.1448. M. pt. found: $245-248{ }^{\circ} \mathrm{C}$. FT-IR (ATR): $\bar{v} / \mathrm{cm}^{-1}: 3150-$ 3400, 2931, 2875, 1537, 1514, 1330, 1172. UV $\lambda_{\max }\left(0.1 \mathrm{mM}\right.$ in DMSO): $327 \mathrm{~nm}\left(\varepsilon=33,000 \mathrm{~cm}^{-1} \mathrm{M}^{-1}\right)$. TGA (Air): Weight loss at $300{ }^{\circ} \mathrm{C}(5.65 \%)$; Onset temperature $\left(314{ }^{\circ} \mathrm{C}\right) .{ }^{1} \mathrm{H}$ NMR $\left(500 \mathrm{MHz}, \mathrm{DMSO}-d_{6}\right) \delta: 3.69-3.71(\mathrm{~m}, 2 \mathrm{H})$, $3.96(\mathrm{t}, J 4.9 \mathrm{~Hz}, 2 \mathrm{H}), 4.89(\mathrm{t}, J 5.5 \mathrm{~Hz}, 1 \mathrm{H}), 5.98(\mathrm{~s}, 2 \mathrm{H}), 7.63-7.66(\mathrm{~m}, 4 \mathrm{H}), 7.72(\mathrm{t}, J 7.3 \mathrm{~Hz}, 2 \mathrm{H}), 8.34(\mathrm{~d}, J 7.3 \mathrm{~Hz}$, $4 \mathrm{H}), 13.51(\mathrm{~s}, 2 \mathrm{H}) .{ }^{13} \mathrm{C}$ NMR $\left(100 \mathrm{MHz}, \mathrm{DMSO}-d_{6}\right) \delta: 59.8,70.3,95.0,97.1,129.0,129.8,134.2,134.3,164.5$, $165.8,168.9,171.0$.

2,4-Dichloro-6-phenyl-1,3,5-triazine (20). $1 \mathrm{M}$ Phenylmagnesium bromide in THF (110 mL, $11.00 \mathrm{mmol}) \mathrm{was}$ added dropwise to a solution of cyanuric chloride $(20.00 \mathrm{~g}, 10.84 \mathrm{mmol})$ in anhydrous THF (300 $\mathrm{mL}) \mathrm{under}$ nitrogen, whilst maintaining the temperature at $0{ }^{\circ} \mathrm{C}$. Once the addition was complete, the mixture was stirred at $0{ }^{\circ} \mathrm{C}$ for 4 hours and poured into $10 \% \mathrm{v} / \mathrm{v}$ aqueous $\mathrm{HCl}(200 \mathrm{~mL})$. The THF was removed under reduced pressure and the organic product was extracted with $\mathrm{CHCl}_{3}(3 \times 150 \mathrm{~mL})$. The organic layer was combined and washed with water $(2 \times 150 \mathrm{~mL})$ and brine $(100 \mathrm{~mL})$, dried over anhydrous sodium sulfate and the solvent was removed under reduced pressure. The crude product was purified by grinding into a fine powder, suspending and washing with $\mathrm{MeOH}(3 \times 100 \mathrm{~mL})$. This yielded a white powder which was dried at $70{ }^{\circ} \mathrm{C}$ in vacuo (60 mbar) to yield 20 (15.67 g, 64\%). HRMS: found $\mathrm{m} / \mathrm{z} 226.0121(\mathrm{M}+\mathrm{H})^{+}$; calculated $\mathrm{m} / \mathrm{z} 225.9933$. M. pt. expected: 118$120^{\circ} \mathrm{C} ;{ }^{43}$ found: $118-120^{\circ} \mathrm{C}$. FT-IR (ATR): $\bar{v} / \mathrm{cm}^{-1}: 3030,1523,1494 .{ }^{1} \mathrm{H} \mathrm{NMR}\left(400 \mathrm{MHz}, \mathrm{CDCl}_{3}\right) \delta: 7.52-7.56(\mathrm{~m}$, $2 \mathrm{H}), 7.65-7.69(\mathrm{~m}, 1 \mathrm{H}), 8.50-8.52(\mathrm{~m}, 2 \mathrm{H}) .{ }^{13} \mathrm{C} \mathrm{NMR}\left(100 \mathrm{MHz}, \mathrm{CDCl}_{3}\right) \delta: 129.3,130.1,132.9,134.9,172.3,175.1$. 2,4-Dichloro-6-(4-methoxyphenyl)-1,3,5-triazine (21). $0.5 \mathrm{M}$ 4-Methoxyphenylmagnesium bromide in THF (20 $\mathrm{mL}, 10.00 \mathrm{mmol}$ ) was added to a stirred solution of cyanuric chloride $(1.84 \mathrm{~g}, 10.00 \mathrm{mmol})$ in anhydrous THF (25 $\mathrm{mL}$ ) under nitrogen, whilst maintaining the temperature at $0{ }^{\circ} \mathrm{C}$. Once the addition was complete, the reaction mixture was stirred at $0{ }^{\circ} \mathrm{C}$ for 4 hours and then poured into cold $10 \% \mathrm{v} / \mathrm{v}$ aqueous $\mathrm{HCl}(50 \mathrm{~mL})$. The THF was removed under reduced pressure and the organic product was extracted with $\mathrm{CHCl}_{3}(2 \times 50 \mathrm{~mL})$. The organic layer was washed with water $(2 \times 100 \mathrm{~mL})$, brine $(100 \mathrm{~mL})$, dried over anhydrous sodium sulfate and the solvent removed under reduced pressure. The crude solid was purified by grinding into a fine powder, suspending and washing with $\mathrm{MeOH}(3 \times 100 \mathrm{~mL})$. The white coloured product was dried at $40{ }^{\circ} \mathrm{C}$ in vacuo $(60 \mathrm{mbar})$ to yield 21 (1.20 g, 47\%). HRMS: found $\mathrm{m} / \mathrm{z} 256.0036$ [M] ${ }^{+}$; calculated $\mathrm{m} / \mathrm{z} 256.0039$. M. pt. expected: $137-138^{\circ} \mathrm{C} ; 4^{44}$ found: 137-138 ${ }^{\circ} \mathrm{C}$. FT-IR (ATR): $\bar{v} / \mathrm{cm}^{-1}: 3078,2974,2937,1516,1477,1244 .{ }^{1} \mathrm{H} \mathrm{NMR}\left(500 \mathrm{MHz}, \mathrm{CDCl}_{3}\right) \delta: 3.92(\mathrm{~s}, 3 \mathrm{H})$,

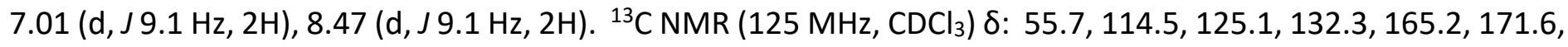
174.2.

4,4'-(6-Phenyl-1,3,5-triazine-2,4-diyl)bis(benzene-1,3-diol) (22). A mixture of 2,4-dichloro-6-phenyl-1,3,5triazine 20 (8.00 g, $0.035 \mathrm{~mol})$ and resorcinol (7.99. g, $0.073 \mathrm{~mol})$ in anhydrous 1,2-dichloroethane $(250 \mathrm{~mL}) \mathrm{was}$ warmed to $70{ }^{\circ} \mathrm{C}$ under nitrogen. Once the resorcinol had dissolved, the reaction mixture was cooled to $40{ }^{\circ} \mathrm{C}$ and $\mathrm{AlCl}_{3}(9.68 \mathrm{~g}, 0.073 \mathrm{~mol})$ was added. The mixture was heated to $55^{\circ} \mathrm{C}$, and a dark red coloured precipitate formed after 1 hour which prevented stirring. The reaction was kept at $55{ }^{\circ} \mathrm{C}$ without stirring for a further 16 hours. The mixture was cooled to room temperature, water $(200 \mathrm{~mL})$ was added and the supernatant removed. The solid residue remaining in the reaction flask was suspended in hot $\mathrm{MeOH} /$ water $(50 / 50, \mathrm{v} / \mathrm{v}, 250 \mathrm{~mL})$ and ultrasonicated at $55^{\circ} \mathrm{C}$ for 1 hour. The yellow coloured solid was collected by filtration and washed with $\mathrm{MeOH}$ 
$(100 \mathrm{~mL})$ and dried at $70{ }^{\circ} \mathrm{C}$ in vacuo $(60 \mathrm{mbar})$ to yield $22(8.97 \mathrm{~g}, 68 \%)$. No further purification was necessary and the yellow coloured crude solid was used in the subsequent step. HRMS: found $m / z 374.1132(\mathrm{M}+\mathrm{H})^{+}$; calculated $m / z$ 374.1135. M. pt. found: $335-338^{\circ} \mathrm{C}$. FT-IR (ATR): $\bar{v} / \mathrm{cm}^{-1}: 3200-3350,3020,1508,1101$. UV $\lambda_{\max }$ (0.1 mM in DMSO): $352 \mathrm{~nm}\left(\varepsilon=36,000 \mathrm{~cm}^{-1} \mathrm{M}^{-1}\right)$. TGA (Air): Weight loss at $300^{\circ} \mathrm{C}(0.27 \%)$; Onset temperature $\left(415^{\circ} \mathrm{C}\right) .{ }^{1} \mathrm{H}$ NMR $(500 \mathrm{MHz}, \mathrm{DMSO}) \delta: 6.36$ (d, J $\left.2.3 \mathrm{~Hz}, 2 \mathrm{H}\right), 6.51$ (dd, J 8.8, 2.3 Hz, 2H), 7.62-7.65 (m, $\left.2 \mathrm{H}\right), 7.71$ (t, J $7.3 \mathrm{~Hz}, 1 \mathrm{H}), 8.27$ (d, J $8.8 \mathrm{~Hz}, 2 \mathrm{H}), 8.33$ (d, J $7.3 \mathrm{~Hz}, 2 \mathrm{H}), 10.49$ (s, 2H), $13.03(\mathrm{~s}, 2 \mathrm{H}) .{ }^{13} \mathrm{C} \mathrm{NMR}(100 \mathrm{MHz}$, DMSO) $\delta: 103.6,109.3,109.4,128.7,129.7,131.9,133.8,134.8,164.2,164.8,168.3,169.8$.

4,4'-(6-(4-Methoxyphenyl)-1,3,5-triazine-2,4-diyl)bis(benzene-1,3-diol) (23). $\mathrm{AlCl}_{3}$ (1.19 g, $8.92 \mathrm{mmol}$ ) was added to a solution of 2,4-dichloro-6-(4-methoxyphenyl)-1,3,5-triazine 21 (1.00 g, $3.90 \mathrm{mmol}$ ) and resorcinol $(0.99 \mathrm{~g}, 9.00 \mathrm{mmol})$ in 1,2-dichlorobenzene $(25 \mathrm{~mL})$ and the mixture was stirred at $130{ }^{\circ} \mathrm{C}$ for 1 hour under nitrogen. A precipitate formed which was broken up using a glass rod and the reaction mixture was stirred at $130{ }^{\circ} \mathrm{C}$ for 16 hours. The mixture was cooled to room temperature, $10 \% \mathrm{v} / \mathrm{v}$ aqueous $\mathrm{HCl}(30 \mathrm{~mL}$ ) was added and stirred for 30 mins. The suspension was spun in a centrifuge (2000 rpm, $2 \mathrm{mins}$ ) and the supernatant was removed. The residue was resuspended in water $(30 \mathrm{~mL})$, spun in a centrifuge (2000 rpm, 2 mins) and the supernatant was removed. The solid residue was collected by filtration, washed with water $(100 \mathrm{~mL})$ and dried at $70{ }^{\circ} \mathrm{C}$ in vacuo (60 mbar). The crude brown coloured solid was purified by dissolving in hot DMF (10 mL) and precipitating the product with cold water $(20 \mathrm{~mL})$. The precipitate was collected by filtration, washed with water $(100 \mathrm{~mL})$ and the yellow coloured solid was dried at $70^{\circ} \mathrm{C}$ in vacuo (60 mbar) to yield 23 (1.12 g, 71\%). HRMS: found $\mathrm{m} / \mathrm{z} 404.1245(\mathrm{M}+\mathrm{H})^{+}$; calculated $\mathrm{m} / \mathrm{z}$ 404.1241. M. pt. found: $>360^{\circ} \mathrm{C}$. FT-IR (ATR): $\bar{v} / \mathrm{cm}^{-1}: 2900-3600$, 3022, 2850, 1506, 1165. UV $\lambda_{\max }\left(0.1 \mathrm{mM}\right.$ in DMSO): $343 \mathrm{~nm}\left(\varepsilon=46,000 \mathrm{~cm}^{-1} \mathrm{M}^{-1}\right)$. TGA (Air): Weight loss at $300{ }^{\circ} \mathrm{C}(3.17 \%)$; Onset temperature $\left(354{ }^{\circ} \mathrm{C}\right) .{ }^{1} \mathrm{H}$ NMR $\left(400 \mathrm{MHz}, \mathrm{DMSO}-d_{6}\right) \delta: 3.88(\mathrm{~s}, 3 \mathrm{H}), 6.36(\mathrm{~d}, J 2.3 \mathrm{~Hz}, 2 \mathrm{H})$, $6.50(\mathrm{dd}, J$ 8.8, $2.3 \mathrm{~Hz}, 2 \mathrm{H}), 7.16(\mathrm{~d}, J 9.0 \mathrm{~Hz}, 2 \mathrm{H}), 8.23-8.28(\mathrm{~m}, 4 \mathrm{H}), 10.46(\mathrm{~s}, 2 \mathrm{H}), 13.35(\mathrm{~s}, 2 \mathrm{H}) .{ }^{13} \mathrm{C} \mathrm{NMR}(100$ $\left.\mathrm{MHz}, \mathrm{DMSO}-d_{6}\right) \delta: 55.6,103.1,108.78,108.82,114.6,126.2,130.2,131.2,163.6,163.7,164.2,167.1,169.1$.

6,6'-(6-Phenyl-1,3,5-triazine-2,4-diyl)bis(3-(2-hydroxyethoxy)phenol) (24). A mixture of 4,4'-(6-phenyl-1,3,5triazine-2,4-diyl)bis(benzene-1,3-diol) 22 (3.00 g, $8.04 \mathrm{mmol}$ ) and $\mathrm{Na}_{2} \mathrm{CO}_{3}$ (4.26 g, $40.20 \mathrm{mmol}$ ) in DMF (200 mL) was heated to $70{ }^{\circ} \mathrm{C}$ whilst stirring. A solution of 2 -bromoethanol $(2.50 \mathrm{~g}, 20.00 \mathrm{mmol})$ in DMF $(100 \mathrm{~mL}) \mathrm{was}$ added slowly. Once the addition was complete, the mixture was stirred at $110^{\circ} \mathrm{C}$ for 16 hours. The mixture was cooled to $70{ }^{\circ} \mathrm{C}$ and a second solution of 2-bromoethanol $(2.50 \mathrm{~g}, 20.00 \mathrm{mmol})$ in DMF (100 mL) was added dropwise. Once the addition was complete, the mixture was stirred at $110{ }^{\circ} \mathrm{C}$ for an additional 16 hours. The mixture was filtered whilst hot, the solvent removed under reduced pressure and the residue was redissolved in ethyl acetate/MeOH $(8 / 2, \mathrm{v} / \mathrm{v}, 100 \mathrm{~mL})$. The organic layer was washed with $5 \% \mathrm{v} / \mathrm{v}$ aqueous acetic acid (50 $\mathrm{mL}), 0.25 \mathrm{M}$ aqueous $\mathrm{NaHCO}_{3}(50 \mathrm{~mL})$ and brine $(50 \mathrm{~mL})$. The organic layer was dried using sodium sulfate and the solvent removed under reduced pressure. The light yellow solid was suspended in $\mathrm{MeOH}(25 \mathrm{~mL})$, filtered and dried at $70{ }^{\circ} \mathrm{C}$ in vacuo (60 mbar) to yield 24 (1.50 g, 41\%). HRMS: found $\mathrm{m} / \mathrm{z} 462.1660(\mathrm{M}+\mathrm{H})^{+}$; calculated $m / z$ 462.1660. M. pt. found: 222-225 ${ }^{\circ} \mathrm{C}$. FT-IR (ATR): $\bar{v} / \mathrm{cm}^{-1}: 3150-3400,2921,2879,1537,1508,1290,1232$. UV $\lambda_{\max }\left(0.1 \mathrm{mM}\right.$ in DMSO): $349 \mathrm{~nm}\left(\varepsilon=37,000 \mathrm{~cm}^{-1} \mathrm{M}^{-1}\right)$. TGA (Air): Weight loss at $300{ }^{\circ} \mathrm{C}(1.74 \%)$; Onset temperature $\left(388^{\circ} \mathrm{C}\right) .{ }^{1} \mathrm{H}$ NMR $(400 \mathrm{MHz}, \mathrm{DMSO}) \delta: 3.73-3.77(\mathrm{~m}, 4 \mathrm{H}), 4.06(\mathrm{t}, J 4.8 \mathrm{~Hz}, 4 \mathrm{H}), 4.93(\mathrm{t}, J 5.6 \mathrm{~Hz}$, $2 \mathrm{H}), 6.51(\mathrm{~d}, J 2.4 \mathrm{~Hz}, 2 \mathrm{H}), 6.62(\mathrm{dd}, J$ 9.0, $2.4 \mathrm{~Hz}, 2 \mathrm{H}), 7.63-7.67(\mathrm{~m}, 2 \mathrm{H}), 7.73(\mathrm{~m}, 1 \mathrm{H}), 8.31-8.36(\mathrm{~m}, 4 \mathrm{H}), 13.03$ (s, 2H). ${ }^{13} \mathrm{C}$ NMR (100 MHz, DMSO) $\delta: 59.3,69.9,101.8,108.2,109.8,128.1,129.2,131.0,133.4,134.1,163.5$, $164.7,167.8,169.1$.

6,6'-(6-Phenyl-1,3,5-triazine-2,4-diyl)bis(3-((9-hydroxynonyl)oxy)phenol) (25). A mixture of 4,4'-(6-phenyl1,3,5-triazine-2,4-diyl)bis(benzene-1,3-diol) 22 (2.00 g, $5.40 \mathrm{mmol}$ ) and $\mathrm{Na}_{2} \mathrm{CO}_{3}(2.27 \mathrm{~g}, 21.60 \mathrm{mmol})$ in DMF $(150 \mathrm{~mL})$ was heated to $70{ }^{\circ} \mathrm{C}$ whilst stirring. A solution of 9-bromo-1-nonanol $(3.01 \mathrm{~g}, 13.50 \mathrm{mmol})$ in DMF (100 $\mathrm{mL}$ ) was added slowly. Once the addition was complete, the mixture was stirred at $110^{\circ} \mathrm{C}$ for 16 hours. The 
mixture was filtered whilst hot, the solvent removed under reduced pressure and the residue was redissolved in $\mathrm{CHCl}_{3}(100 \mathrm{~mL})$. The organic layer was washed with $5 \% \mathrm{v} / \mathrm{v}$ aqueous acetic acid $(30 \mathrm{~mL}), 0.25 \mathrm{M}$ aqueous $\mathrm{NaHCO}_{3}(30 \mathrm{~mL})$ and brine $(50 \mathrm{~mL})$. The organic layer was dried over sodium sulfate and the solvent removed under reduced pressure. The crude product was suspended in $\mathrm{MeOH}(25 \mathrm{~mL})$, filtered and dried at $70{ }^{\circ} \mathrm{C}$ in vacuo (60 mbar). The crude product was purified by flash column chromatography on silica gel $\left(100 \% \mathrm{CHCl}_{3}\right.$, switching to $10 \% \mathrm{MeOH}$, Rf value for 25 in $10 \% \mathrm{MeOH}$ in $\mathrm{CHCl}_{3}=0.8$ ). The solvent was removed under reduced pressure and the yellow coloured solid was dried at $70{ }^{\circ} \mathrm{C}$ in vacuo (60 mbar) to yield 25 (1.01 g, 28\%). HRMS: found $\mathrm{m} / \mathrm{z} 658.3851(\mathrm{M}+\mathrm{H})^{+}$; calculated $\mathrm{m} / \mathrm{z} 658.3851$. M. pt. found: $128-130{ }^{\circ} \mathrm{C}$. FT-IR (ATR): $\bar{v} / \mathrm{cm}^{-1}: 3100-$ 3500, 2922, 2850, 1504, 1533, 1504, 1290, 1234. UV $\lambda_{\max }\left(0.1 \mathrm{mM}\right.$ in $\left.\mathrm{CHCl}_{3}\right): 357 \mathrm{~nm}\left(\varepsilon=37,000 \mathrm{~cm}^{-1} \mathrm{M}^{-1}\right)$. TGA (Air): Weight loss at $300{ }^{\circ} \mathrm{C}(0 \%)$; Onset temperature $\left(41{ }^{\circ} \mathrm{C}\right) .{ }^{1} \mathrm{H} N M R\left(500 \mathrm{MHz}, \mathrm{CDCl}_{3}\right) \delta: 1.36-1.62(\mathrm{~m}, 26 \mathrm{H})$, 1.78-1.83 (m, 4H), 3.64-3.67 (t, J $6.8 \mathrm{~Hz}, 4 \mathrm{H}), 3.99(\mathrm{t}, J 6.6 \mathrm{~Hz}, 4 \mathrm{H}), 6.46(\mathrm{~d}, J 2.4 \mathrm{~Hz}, 2 \mathrm{H}), 6.52(\mathrm{dd}, J 9.0,2.4 \mathrm{~Hz}$, $2 \mathrm{H}), 7.53-7.56(\mathrm{~m}, 2 \mathrm{H}), 7.62(\mathrm{~m}, 1 \mathrm{H}), 8.35$ (broad s, $4 \mathrm{H}), 13.38(\mathrm{~s}, 2 \mathrm{H}) .{ }^{13} \mathrm{C} \mathrm{NMR}\left(100 \mathrm{MHz}, \mathrm{CDCl}_{3}\right) \delta: 25.7,26.0$, $29.3,29.4,29.5,29.1,32.8,63.1,68.3,101.8,108.6,110.0,128.7,129.0,131.2,133.3,134.3,164.6$, 165.5. No signals for triazine carbons.

6,6'-(6-(4-Methoxyphenyl)-1,3,5-triazine-2,4-diyl)bis(3-(2-hydroxyethoxy)phenol) (26). A solution of 4,4'-(6(4-methoxyphenyl)-1,3,5-triazine-2,4-diyl)bis(benzene-1,3-diol) 23 (0.25 g, 0.62 mmol) and $\mathrm{Na}_{2} \mathrm{CO}_{3}(0.20 \mathrm{~g}, 1.86$ $\mathrm{mmol})$ in DMF $(15 \mathrm{~mL})$ was stirred at $70^{\circ} \mathrm{C}$. To this, a solution of 2-bromoethanol $(0.23 \mathrm{~g}, 1.86 \mathrm{mmol})$ in DMF (5 $\mathrm{mL}$ ) was added and the reaction mixture was stirred at $110{ }^{\circ} \mathrm{C}$ for 16 hours. The mixture was filtered whilst hot and the solvent removed under reduced pressure. The residue was suspended in $10 \% \mathrm{v} / \mathrm{v}$ aqueous $\mathrm{HCl}(75 \mathrm{~mL})$, ultrasonicated for 20 mins and stirred at room temperature for a further 10 mins. The suspension was spun in a centrifuge (2000 rpm, 2 mins.) and the supernatant removed. The residue was resuspended in water $(20 \mathrm{~mL})$, the solid collected by filtration and washed with more water $(30 \mathrm{~mL})$. The light brown coloured solid was dried at $70{ }^{\circ} \mathrm{C}$ in vacuo (60 mbar) to yield $26(0.20 \mathrm{~g}, 66 \%)$. HRMS: found $\mathrm{m} / \mathrm{z} 492.1772(\mathrm{M}+\mathrm{H})^{+}$; calculated $\mathrm{m} / \mathrm{z}$ 492.1765. M. pt. expected: $155-158^{\circ} \mathrm{C} ;{ }^{44}$ found: $157-158^{\circ} \mathrm{C}$. FT-IR (ATR): $\bar{v} / \mathrm{cm}^{-1}: 3100-3500,2935,1535,1502$, 1255, 1170. UV $\lambda_{\max }\left(0.1 \mathrm{mM}\right.$ in $\left.\mathrm{CHCl}_{3}\right): 342 \mathrm{~nm}\left(\varepsilon=46,000 \mathrm{~cm}^{-1} \mathrm{M}^{-1}\right)$. TGA (Air): Weight loss at $300{ }^{\circ} \mathrm{C}(1.36 \%)$; Onset temperature $\left(331^{\circ} \mathrm{C}\right) .{ }^{1} \mathrm{H}$ NMR $\left(400 \mathrm{MHz}, \mathrm{DMSO}-d_{6}\right) \delta: 3.73-3.76(\mathrm{~m}, 4 \mathrm{H}), 3.87(\mathrm{~s}, 3 \mathrm{H}), 4.02(\mathrm{t}, J 5.7 \mathrm{~Hz}$, $4 \mathrm{H}), 4.96(\mathrm{t}, J 5.5 \mathrm{~Hz}, 2 \mathrm{H}), 6.43(\mathrm{~d}, J 2.4 \mathrm{~Hz}, 2 \mathrm{H}), 6.56$ (dd, J 9.0, $2.4 \mathrm{~Hz}), 7.11(\mathrm{~d}, J 9.0 \mathrm{~Hz}, 2 \mathrm{H}), 8.15-8.18(\mathrm{~m}, 4 \mathrm{H})$, $13.1(\mathrm{~s}, 2 \mathrm{H}) .{ }^{13} \mathrm{C}$ NMR $\left(100 \mathrm{MHz}\right.$, DMSO- $\left.d_{6}\right) \delta: 56.1,59.9,70.4,102.2,108.6,108.2,115.0,126.6,130.4,131.3$, 163.7, 164.1, 165.1, 167.6, 169.4.

General Synthesis procedure for Poly(El-co-UVAMs). A stirred slurry of BHEI was pre-heated at $90{ }^{\circ} \mathrm{C}$ for 30 mins. Once the viscosity of the slurry had reduced sufficiently, the slurry was poured into a polycondensation (PC) tube. To this, UVAM and $\mathrm{Sb}_{2} \mathrm{O}_{3}(0.15 \mathrm{~g}, 0.52 \mathrm{mmol})$ were added and the PC tube was scored lightly on the stem using a Stanley blade, to ensure safe extrusion, and clamped inside a heating block. The PC tube was fitted with a polycondensation head, stirrer guide, air stirrer, delivery side-arm, distillate tube inside an ice-filled Dewar flask, thermocouples and optical revolution counter, and then connected to a gas manifold. The temperature was raised using a control box to $200{ }^{\circ} \mathrm{C}$ over 35 mins. under a nitrogen purge. The air stirrer was then started with a pressure of $8.5 \mathrm{psi}$ and the nitrogen purge was then stopped, with the system now under $950 \mathrm{mbar}$ pressure. The pressure was reduced gradually to less than $10 \mathrm{mbar}$ as the temperature was increased to $285-290^{\circ} \mathrm{C}$ at a rate of $1^{\circ} \mathrm{C} / \mathrm{min}$., with the stirrer speed reaching between $165-175 \mathrm{rpm}$. After stirring at 285$290{ }^{\circ} \mathrm{C}$ for 30 mins., the vacuum was slowly replaced with a nitrogen purge. A hammer and chisel were used to break the stem of the PC rig tube, and the copolymer was extruded and quenched into an ice-water bath. The copolymer lace formed was left to dry in air.

A $10 \% \mathrm{w} / \mathrm{v}$ solution of crude polymer in chloroform was filtered through a cotton wool plug and added dropwise into cold methanol, ensuring a 1:10 v/v ratio of chloroform to methanol. The precipitate which formed was 
filtered and washed with chloroform/methanol (1:10). The precipitate was dried at $40{ }^{\circ} \mathrm{C}$ in vacuo (60 mbar) for 1 hour and this precipitation process was repeated twice more.

Poly(El-co-10) (P1). DSC: $\mathrm{Tg}=66.3^{\circ} \mathrm{C} . \mathrm{GPC}: \overline{M_{w}}=43,100 ; \overline{M_{n}}=17,200 ; \mathrm{Ð}=2.5 .{ }^{1} \mathrm{H} \mathrm{NMR}\left(400 \mathrm{MHz} \mathrm{CDCl}_{3}\right) \delta$ : $1.69(\mathrm{~s}, 0.0110 \mathrm{H}), 6.44(\mathrm{~d}, J 2.4 \mathrm{~Hz}, 0.0031 \mathrm{H}), 6.55(\mathrm{dd}, J 8.9,2.5 \mathrm{~Hz}, 0.0031 \mathrm{H}), 4.68(\mathrm{~s}, 4 \mathrm{H}), 7.50(\mathrm{t}, J 7.8 \mathrm{~Hz}, 1 \mathrm{H})$, 8.21 (dd, J 7.8, $1.5 \mathrm{~Hz}, 2 \mathrm{H}), 8.69(\mathrm{~s}, 1 \mathrm{H}), 13.28(\mathrm{~s}, 0.0034 \mathrm{H})$

Poly(El-co-12) (P2). DSC: Tg $=67.1{ }^{\circ} \mathrm{C} . \mathrm{GPC}: \overline{M_{w}}=38,500 ; \overline{M_{n}}=14,400 ; \bigoplus=2.7 .{ }^{1} \mathrm{H} \mathrm{NMR}(400 \mathrm{MHz} \mathrm{CDCl})_{3} \delta$ : $4.68(\mathrm{~s}, 4 \mathrm{H}), 6.60(\mathrm{~d}, J 2.5 \mathrm{~Hz}, 0.0035 \mathrm{H}), 6.62-6.65(\mathrm{~m}, 0.0037 \mathrm{H}), 7.50(\mathrm{t}, J 7.8 \mathrm{~Hz}, 1 \mathrm{H}), 8.21(\mathrm{dd}, J 7.8,1.7 \mathrm{~Hz}, 2 \mathrm{H})$, $8.69(\mathrm{~s}, 1 \mathrm{H}), 13.46(\mathrm{~s}, 0.0042 \mathrm{H})$

Poly(El-co-13) (P3). DSC: $\mathrm{Tg}=65.8{ }^{\circ} \mathrm{C} . \mathrm{GPC}: \overline{M_{w}}=55,000 ; \overline{M_{n}}=14,200 ; \bigoplus=3.9 .{ }^{1} \mathrm{H} \mathrm{NMR}\left(400 \mathrm{MHz}, \mathrm{CDCl}_{3}\right) \delta$ : $4.68(\mathrm{~s}, 4 \mathrm{H}), 6.58(\mathrm{~d}, J 2.2 \mathrm{~Hz}, 0.0024 \mathrm{H}), 6.62(\mathrm{dd}, J 9.0,2.2 \mathrm{~Hz}, 0.0024 \mathrm{H}), 7.50(\mathrm{t}, J 7.8 \mathrm{~Hz}, 1 \mathrm{H}), 8.21$ (dd, J 7.8, 1.7 $\mathrm{Hz}, 2 \mathrm{H}), 8.69(\mathrm{~s}, 1 \mathrm{H}), 13.69(\mathrm{~s}, 0.0036 \mathrm{H})$

Poly(El-co-14) (P4). DSC: $\mathrm{Tg}=66.6{ }^{\circ} \mathrm{C} . \mathrm{GPC}: \overline{M_{w}}=51,000 ; \overline{M_{n}}=11,800 ; \bigoplus=4.3 .{ }^{1} \mathrm{H} \mathrm{NMR}(400 \mathrm{MHz}, \mathrm{CDCl} 3) \delta$ : $4.68(\mathrm{~s}, 4 \mathrm{H}), 6.58(\mathrm{~d}, J 2.4 \mathrm{~Hz}, 0.0040 \mathrm{H}), 6.62-6.65(\mathrm{~m}, 0.0039 \mathrm{H}) 7.50(\mathrm{t}, J 7.8 \mathrm{~Hz}, 1 \mathrm{H}), 8.21(\mathrm{dd}, J 7.8,1.6 \mathrm{~Hz}, 2 \mathrm{H})$, $8.69(\mathrm{~s}, 1 \mathrm{H}), 13.33(\mathrm{~s}, 0.0056 \mathrm{H})$

Poly(El-co-15) (P5). DSC: $\mathrm{Tg}=67.5^{\circ} \mathrm{C} . \mathrm{GPC}: \overline{M_{w}}=54,200 ; \overline{M_{n}}=16,000 ; \bigoplus=3.4 .{ }^{1} \mathrm{H} \mathrm{NMR}(400 \mathrm{MHz}, \mathrm{CDCl} 3) \delta$ : $4.68(\mathrm{~s}, 4 \mathrm{H}), 6.16(\mathrm{~s}, 0.0078 \mathrm{H}), 7.50(\mathrm{t}, J 7.8 \mathrm{~Hz}, 1 \mathrm{H}), 8.21(\mathrm{dd}, J 7.8,1.7 \mathrm{~Hz}, 2 \mathrm{H}), 8.69(\mathrm{~s}, 1 \mathrm{H}), 13.67(\mathrm{~s}, 0.0072 \mathrm{H})$ Poly(El-co-16) (P6). DSC: $\mathrm{Tg}=66.8{ }^{\circ} \mathrm{C} . \mathrm{GPC}: \overline{M_{w}}=33,300 ; \overline{M_{n}}=12,200 ; \bigoplus=2.7 .{ }^{1} \mathrm{H} \mathrm{NMR}(400 \mathrm{MHz} \mathrm{CDCl}) \delta$ : $4.68(\mathrm{~s}, 4 \mathrm{H}), 6.61-6.67(\mathrm{~m}, 0.0035 \mathrm{H}), 7.50(\mathrm{t}, J 7.8 \mathrm{~Hz}, 1 \mathrm{H}), 8.21(\mathrm{dd}, J 7.8,1.6 \mathrm{~Hz}, 2 \mathrm{H}), 8.69(\mathrm{~s}, 1 \mathrm{H}), 13.54(\mathrm{~s}$, $0.0032 \mathrm{H})$

Poly(El-co-17) (P7). DSC: $\mathrm{Tg}=66.1{ }^{\circ} \mathrm{C} . \mathrm{GPC}: \overline{M_{w}}=44,900 ; \overline{M_{n}}=12,900 ; \bigoplus=3.5 .{ }^{1} \mathrm{H} \mathrm{NMR}(400 \mathrm{MHz}, \mathrm{CDCl} 3) \delta$ : $4.68\left(\mathrm{~s}, 4 \mathrm{H}, \mathrm{H}_{4}\right), 6.57(\mathrm{~d}, J 1.9 \mathrm{~Hz}, 0.0030 \mathrm{H}), 6.62(\mathrm{dd}, J 7.1,1.9 \mathrm{~Hz}, 0.0030 \mathrm{H}), 7.50(\mathrm{t}, J 7.8 \mathrm{~Hz}, 1 \mathrm{H}), 8.21(\mathrm{dd}, J 7.8$, $1.7 \mathrm{~Hz}, 2 \mathrm{H}), 8.69(\mathrm{~s}, 1 \mathrm{H}), 13.71(\mathrm{~s}, 0.0041 \mathrm{H})$

Poly(El-co-18) (P8). DSC: $\mathrm{Tg}=66.1{ }^{\circ} \mathrm{C} . \mathrm{GPC}: \overline{M_{w}}=21,000 ; \overline{M_{n}}=7,800 ; \bigoplus=2.6 .{ }^{1} \mathrm{H} \mathrm{NMR}\left(400 \mathrm{MHz}, \mathrm{CDCl}_{3}\right) \delta$ : $4.68(\mathrm{~s}, 4 \mathrm{H}), 6.58(\mathrm{~s}, 0.0033 \mathrm{H}), 6.62-6.65(\mathrm{~m}, 0.0035 \mathrm{H}), 7.50(\mathrm{t}, J 7.8 \mathrm{~Hz}, 1 \mathrm{H}), 8.21(\mathrm{dd}, J 7.8,1.7 \mathrm{~Hz}, 2 \mathrm{H}), 8.69(\mathrm{~s}$, $1 \mathrm{H}), 13.35$ (s, 0.0040H)

Poly(El-co-19) (P9). DSC: $\mathrm{Tg}=65.1^{\circ} \mathrm{C} . \mathrm{GPC}: \overline{M_{w}}=23,700 ; \overline{M_{n}}=7,900 ; \bigoplus=3.0 .{ }^{1} \mathrm{H} \mathrm{NMR}(500 \mathrm{MHz}, \mathrm{CDCl} 3) \delta$ : $4.68(\mathrm{~s}, 4 \mathrm{H}), 6.16(\mathrm{~s}, 0.0060 \mathrm{H}), 7.50(\mathrm{t}, J 7.8 \mathrm{~Hz}, 1 \mathrm{H}), 8.21(\mathrm{~d}, J 7.8 \mathrm{~Hz}, 2 \mathrm{H}), 8.69(\mathrm{~s}, 1 \mathrm{H}), 13.63(\mathrm{~s}, 0.0068 \mathrm{H})$

Poly(El-co-24) (P10). DSC: $\mathrm{Tg}=68.3^{\circ} \mathrm{C}$. GPC: $\overline{M_{w}}=107,000 ; \overline{M_{n}}=28,500 ; \bigoplus=3.8 .{ }^{1} \mathrm{H} \mathrm{NMR}\left(400 \mathrm{MHz} \mathrm{CDCl}_{3}\right)$ $\delta: 4.68(\mathrm{~s}, 4 \mathrm{H}), 6.56-6.58(\mathrm{~m} 0.0058 \mathrm{H}) 6.63(\mathrm{~d}, J 8.0 \mathrm{~Hz}, 0.0060 \mathrm{H}), 7.50(\mathrm{t}, J 7.8 \mathrm{~Hz}, 1 \mathrm{H}), 8.21(\mathrm{dd}, J 7.8,1.7 \mathrm{~Hz}$, $2 \mathrm{H}), 8.69(\mathrm{~s}, 1 \mathrm{H}), 13.38(\mathrm{~s}, 0.0056 \mathrm{H})$

Poly(El-co-25) (P11). DSC: $\mathrm{Tg}=57.6{ }^{\circ} \mathrm{C} . \mathrm{GPC}: \overline{M_{w}}=45,700 ; \overline{M_{n}}=15,900 ; \bigoplus=2.9 .{ }^{1} \mathrm{H} \mathrm{NMR}(400 \mathrm{MHz}, \mathrm{CDCl} 3) \delta$ : $4.69(\mathrm{~s}, 4 \mathrm{H}), 6.52-6.60(\mathrm{~m}, 0.0062 \mathrm{H}) 7.51(\mathrm{~s}, 1 \mathrm{H}), 8.21(\mathrm{~s}, 2 \mathrm{H}), 8.70(\mathrm{~s}, 1 \mathrm{H}), 13.43(\mathrm{~s}, 0.0030 \mathrm{H})$

Poly(El-co-26) (P12). DSC: $\mathrm{Tg}=69.2{ }^{\circ} \mathrm{C} . \mathrm{GPC}: \overline{M_{w}}=67,000 ; \overline{M_{n}}=18,100 ; \bigoplus=3.7 .{ }^{1} \mathrm{H} \mathrm{NMR}\left(400 \mathrm{MHz}, \mathrm{CDCl}_{3}\right) \delta$ : $4.68(\mathrm{~s}, 4 \mathrm{H}), 6.56(\mathrm{~d}, J 2.1 \mathrm{~Hz}, 0.0043 \mathrm{H}) 6.63(\mathrm{~d}, J 9.0 \mathrm{~Hz}, 0.0044 \mathrm{H}), 7.50(\mathrm{t}, J 7.8 \mathrm{~Hz}, 1 \mathrm{H}), 8.21(\mathrm{dd}, J 7.8,1.7 \mathrm{~Hz}$, $2 \mathrm{H}), 8.69(\mathrm{~s}, 1 \mathrm{H}), 13.49(\mathrm{~s}, 0.0039 \mathrm{H})$

\section{Acknowledgements}

The authors would like to thank DuPont Teijin Films Limited for funding the PhD studentship for Omer Can Erdemli. 


\section{References}

1. Lee, C. O.; Chae, B.; Kim, S. B.; Jung, Y. M.; Lee, S. W. Vib. Spectrosc. 2012, 60, 142-145. https://doi.org/10.1016/j.vibspec.2011.10.013

2. Keck, J.; Kramer, H.; Port, H. J. Phys. Chem. 1996, 100, 14468-14475. https://doi.org/10.1021/jp961081h

3. Day, M.; Wiles, D. J. Appl. Polym. Sci. 1972, 16, 175-189. https://doi.org/10.1002/app.1972.070160116

4. Day, M.; Wiles, D. J. Appl. Polym. Sci. 1972, 16, 191-202. https://doi.org/10.1002/app.1972.070160118

5. Day, M.; Wiles, D. J. Appl. Polym. Sci. 1972, 16, 203-215. https://doi.org/10.1002/app.1972.070160118

6. Blais, P.; Day, M.; Wiles, D. J. Appl. Polym. Sci. 1973, 17, 1895-1907. https://doi.org/10.1002/app.1973.070170622

7. Fechine, G.; Rabello, M.; Souto-Maior, R. Polym. Degrad. Stab. 2002, 75, 153-159. https://doi.org/10.1016/S0141-3910(01)00214-2

8. Fechine, G.; Christensen, P.; Egerton, T.; White, J. Polym. Degrad. Stab. 2009, 94, 234-239. https://doi.org/10.1016/i.polymdegradstab.2008.10.025

9. Fechine, G.; Rabello, M.; Souto Maior, R.; Catalani L., Polym. J. 2004, 45, 2303-2308. https://doi.org/10.1016/j.polymer.2004.02.003

10. Rivaton, A.; Gardette, J.; Hoyle, C.; Ziemer, M.; Fagerburg, D.; Grossetête T., Polym. J. 2000, 41, 3541-3554. https://doi.org/10.1016/S0032-3861(99)00580-7

11. Catalan, J.; Valle, J.; Diaz, C.; Paz, L. J. Phys. Chem. A 1999, 103, 10921-10934.

https://doi.org/10.1021/ip992631p

12. LeGourriérec, D.; Kharlanov, V.; Brown, R.; Rettig, W. J. Photochem. Photobiol. A Chem. 2000, 130, $101-111$. https://doi.org/10.1016/S1010-6030(99)00206-3

13. Otterstedt, J. J. Chem. Phys. 1973, 58, 5716. https://doi.org/10.1063/1.1679196

14. Crawford, J. Prog. Polym. Sci. 1999, 24, 7-43. https://doi.org/10.1016/S0079-6700(98)00012-4

15. Kuila, D.; Kvakovszky, G.; Murphy, M.; Vicari, R.; Rood, M.; Fritch, K.; Fritch, J.; Wellinghoff, S.; Timmons, S. Chem. Mater. 1999, 11, 109-116.

https://doi.org/10.1021/cm9805121

16. Prucker, O.; Naumann, C.; Rühe, J. J. Am. Chem. Soc. 1999, 121, 8766-8770. https://doi.org/10.1021/ja990962+

17. Rajan, V.; Wäber, R.; Wieser, J. J. Appl. Polym. Sci. 2012, 124, 4007-4015. https://doi.org/10.1002/app.34560

18. Rajan, V.; Wäber, R.; Wieser, J. J. Appl. Polym. Sci. 2012, 124, 3988-3995. https://doi.org/10.1002/app.33878

19. Mizutani, Y.; Kusumoto, K. J. Appl. Polym. Sci. 1975, 19, 713-717. https://doi.org/10.1002/app.1975.070190308

20. Vogl, O.; Albertsson, A.; Janovic, Z. Polym. J., 1985, 26, 1288-1296. https://doi.org/10.1016/0032-3861(85)90301-5

21. Pasch, H.; Shuhaibar, K.; Attari, S. J. Appl. Polym. Sci. 1991, 42, 263-271. 
https://doi.org/10.1002/app.1991.070420130

22. Al-Mobasher, A.; Attari, S.; Pasch, H.; Polym. Bull. 1991, 26, 39-46.

https://doi.org/10.1007/BF00299346

23. Bailey, D.; Tirrell, D.; Vogl, O. J. Polym. Sci. 1976, 14, 2725-2747.

https://doi.org/10.1002/pol.1976.170141113

24. Bailey, D.; Vogl, O. Rev. Macromol. Chem. Phys. 1976, 14, 267-293.

https://doi.org/10.1080/15321797608065772

25. Stein, M.; Keck, J.; Waiblinger, F.; Fluegge, A. P.; Kramer, H. E.; Hartschuh, A.; Port, H.; Leppard, D.; Rytz, G. J. Phys. Chem. A 2002, 106, 2055-2066.

https://doi.org/10.1021/jp012134k

26. Bojinov, V. B.; Polym. Degrad. Stab. 2006, 91, 128-135.

https://doi.org/10.1016/j.polymdegradstab.2005.04.019

27. Bojinov, V. B.; Georgiev, N. I.; Marinova, N. V. Sensors Actuators B Chem. 2010, 148, 6-16. https://doi.org/10.1016/i.snb.2010.05.022

28. Bojinov V. B.; Simeonov, D. B. Polym. Degrad. Stab. 2010, 95, 43-52.

https://doi.org/10.1016/j.polymdegradstab.2009.10.012

29. Bojinov, V. B.; Panova, I. P.; Simeonov, D. B. Dye. Pigment. 2009, 83, 135-143.

https://doi.org/10.1016/j.dyepig.2008.10.007

30. Bojinov, V. B.; Georgiev, N. I.; Bosch, P. J. Fluoresc. 2009, 19, 127-39.

https://doi.org/10.1007/s10895-008-0394-2

31. Bojinov, V. B.; Panova, I. P.; Simeonov, D. B. Dye. Pigment., 2008, 78, 101-110.

https://doi.org/10.1016/i.dyepig.2007.10.010

32. Bojinov V. B.; Panova, I. P. Polym. Degrad. Stab. 2008, 93, 1142-1150.

https://doi.org/10.1016/i.polymdegradstab.2008.03.003

33. Bojinov V. B.; Simeonov, D. B. J. Photochem. Photobiol. A Chem. 2006, 180, 205-212.

https://doi.org/10.1016/i.jphotochem.2005.10.018

34. Blotny, G. Tetrahedron 2006, 62, 9507-9522.

https://doi.org/10.1016/i.tet.2006.07.039

35. Keck, J.; Roessler, M.; Schroeder, C.; Stueber, G. J.; Waiblinger, F.; Stein, M.; Legourrie, D.; Kramer, H. E. A.; Hoier, H.; Henkel, O. S.; Fischer, P.; Port, H.; Hirsch, T.; Rytz, G.; Hayoz, P. J. Phys. Chem. B 1998, 36, 69756985.

https://doi.org/10.1021/jp9818380

36. Moriyama, M.; Kosuge, M.; Tobita, S.; Shizuka, H. Chem. Phys.2000, 253, 91-103.

https://doi.org/10.1016/S0301-0104(99)00377-8

37. Dobashi, Y.; Kondou, J.; Ohkatsu, Y. Polym. Degrad. Stab. 2005, 89, 140-144.

https://doi.org/10.1016/j.polymdegradstab.2005.01.010

38. Dobashi Y.; Ohkatsu, Y. Polym. Degrad. Stab. 2008, 93, 436-447.

https://doi.org/10.1016/i.polymdegradstab.2007.11.011

39. Shultz A.; Leahy, S. J. Appl. Polym. Sci. 1961, 5, 64-66.

https://doi.org/10.1002/app.1961.070051310

40. Harris, J. Aust. J. Chem. 1981, 34, 623-626.

https://doi.org/10.1071/CH9810623

41. Yanagida, S.; Hayama, H.; Yokoe, M.; Komori, S. J. Org. Chem. 1969, 34, 4125-4127.

https://doi.org/10.1021/jo01264a079 
42. Shafer, T.; Wenderborn, F.; Gerster, M.; Hayoz, P.; Schmidhalter, B.; Budry, Ciba Specialty Chemicals Holding Inc., WO2004106311, 2004.

43. Schmelzer, H.; Degener, E.; Holtschmidt, H. Angew. Chem. 1966, 5, 4-5.

https://doi.org/10.1002/anie.196808561

44. Jiang, W. F.; Wang, H. L.; Li, Z. Q. J. Chem. Res. 2008, 664-665.

https://doi.org/10.3184/030823408X375142

This paper is an open access article distributed under the terms of the Creative Commons Attribution (CC BY) license (http://creativecommons.org/licenses/by/4.0/) 